\title{
Nondestructive Evaluation Methods for Quality Acceptance of Installed Building Materials
}

\author{
James R. Clifton* and Nicholas J. Carino* \\ National Bureau of Standards, Washington, DC 20234
}

July 29, 1982

\begin{abstract}
A review of methods developed for the nondestructive evaluation (NDE) of building materials is presented. The generic features of NDE methods are discussed. This is followed by descriptions of specific methods. The principles underlying the operation of the methods are described, along with their typical applications, advantages, and limitations. A table is included summarizing the characteristics of various NDE methods.
\end{abstract}

Key words: building materials; concrete; evaluation; inspection; inplace testing; nondestructive testing; quality assurance.

\section{INTRODUCTION}

A nondestructive evaluation (NDE) method refers to a procedure for obtaining information about the properties of an object without altering that object, and contrasts with traditional destructive tests which permanently damage test objects. Another significant characteristic of many NDE methods is that they are capable of performing measurements not only on laboratory specimens but also on objects "in-situ." It is the latter attribute which makes NDE methods extremely valuable in the area of building technology. With today's emphasis on rehabilitation and renovation, as opposed to new construction, there is a need for methods to evaluate the condition of existing structures. Such an assessment is required in order to develop the best renovation scheme. In addition, NDE methods are valuable tools for periodic inspections of structural components to determine the degree of deterioration, if any, which may occur during service conditions. Finally, these methods may be used for quality assurance purposes to determine whether or not an item has been fabricated as intended. The purpose of this article is to review the NDE methods which have been developed for the examination of materials and structural components.

NDE methods typically measure the properties that are desired in an indirect manner, that is, they measure a characteristic which is somehow related to the property in question. Thus, the accuracy of property measurements based on NDE methods will depend on several factors. First, it will depend on the relationship between the desired property and the quantity actually

*Center for Building Technology, National Meagurement Laboratory. measured by the NDE method. If the relationship is strong, then the property can be estimated quite accurately by means of the indirect measurement. Second, the accuracy will depend on how insensitive the indirect measurement is to factors which do not affect the property in question. For example, if an NDE method is used to estimate the strength of a material and if the NDE measurement is strongly influenced by the moisture content while strength is not, then the strength estimate will be imprecise unless corrections are made for the actual moisture content. Finally, the accuracy will depend on the precision of the NDE measurement. Thus, prior to employing an NDE method, the user must be fully aware of the principles and limitations inherent to the method. Otherwise, incorrect interpretations will result.

The material property of most interest in engineering applications is strength. NDE methods may be used to determine the strength of materials as well as to determine whether or not flaws are present in the material which have an adverse effect on its strength. Some of the indirect measurements used to estimate the desired properties include the velocity of ultrasonic waves through the material, the disturbances of magnetic fields by discontinuities in the material and the absorption of electro-magnetic radiation, such as x-rays. Because of great differences between the properties of metallic and non-metallic building materials, many of the NDE methods are not applicable to both classes of materials.

Steel, concrete and wood are the main structural materials, but the technology of nondestructive evaluation is not equally developed for all three types of materials. The most technically advanced methods are for steel inspection, which is in part due to the com- 
paratively homogenous nature of steel compared to the other materials. Concrete is unique among construction materials in that it is manufactured on-site (or at a nearby concrete plant) using locally available materials. Thus, there is no such thing as a "grade" concrete which has well-defined physical and chemical properties analogous to a "grade" of steel. In addition, concrete is a macroscopically heterogenous material composed of cement, water, sand and rocks. For these reasons, NDE methods have been developed for specific application to concrete, and as will be explained some are not completely "nondestructive." The technology of NDE inspection is least developed for wood.

A key element of many NDE methods is the calibration standard or calibration curve which is necessary to translate the indirect measurement to an estimate of the desired property. The development of the calibration procedure is just as important as the development of the hardware for performing the indirect measurement, and this must be kept in mind when choosing among alternative methods for estimating a desired property. The "cost" of NDE inspection involves not only the cost of the apparatus but also the cost of the calibration. For example, many of the methods used for concrete inspection employ relatively inexpensive test apparatus, but their implementation requires laboratory testing to develop the applicable calibration curve. The need for calibration will be mentioned as each method is discussed.

Having presented this brief introduction to some of the generic characteristics of NDE methods, we will next discuss the principles, applications, advantages and disadvantages of methods which are felt to be applicable for the inspection of building materials and structural components. The methods are presented in alphabetical order beginning with acoustic methods and ending with visual inspection. A special section details a proposed procedure which combines two of the other methods for the purpose of improving the accuracy of strength prediction of concrete. Following this section, the utility of the various NDE methods is discussed in the Summary. Also, displayed in table form for the reader's convenience, is information on commonly used NDE methods, which should prove useful in selecting an NDE method for a specific application.

\section{DESCRIPTION OF NDE METHODS}

\section{Acoustic Emission Method}

In this method, stress waves originating from within the test material or object are detected using surface transducers. [1]. ${ }^{1}$ The acoustic waves are due to the sud-

\footnotetext{
${ }^{1}$ Figures in brackets indicate literature references at the end of this paper.
}

den release of stored strain energy when either preexisting or newly created flaws propogate under the action of an applied stress field. The types of flaw propagation that can be detected include dislocation movement in metals and crack growth in metals or brittle solids such as concrete. Thus, acoustic emission is able to determine the onset of mechanical failure, i.e., yielding or fracture. The test object needs to be stressed so that creation, movement, or propogation of flaws will occur. Static flaws are not detected by acoustic emission.

\subsection{Description of Method}

Acoustic emission testing is a passive technique and only an acoustic wave detection instrument is required. The acoustic waves, which may have a frequency range from audible to ultrasonic, are detected by piezoelectric transducers attached to the surface of the test object. Flaw growth usually can be detected by a transducer located on the test object some distance from the flaw region (provided that the wave amplitude is sufficient to be detected). The transducers generally detect waves in the frequency range of $50 \mathrm{kHz}$ to $10 \mathrm{MHz}$ [1]. Detected signals are amplified and the amount of amplification depends on the source of the acoustic emission; signals from dislocation movement require greater amplification than signals from microcrack propagation. After amplification, the acoustic emission activity is processed and displayed. The most useful data are the rate of acoustic emission events and the cumulative number of events plotted as a function of time, applied load or number of load cycles.

\subsection{Applications}

The method has been used to monitor the in-service behavior of pressure vessels (including nuclear reactors), to detect the onset of rapid crack propagation under fatigue loading or due to stress corrosion, and to monitor the response of systems to proof-load tests. Because acoustic emissions give forewarning of ultimate failure, the technique can be used to indicate when loads should be reduced to prevent total failure. By using multiple pickup of acoustic signals with transducers at different locations and by electronic data processing, it is possible to pinpoint regions of high acoustic emission activity and thereby locate the area of law development or propagation.

\subsection{Advantages and Limitations}

The most significant advantage of the acoustic emission method is that it gives the response of the total struc- 
ture (or system) to applied loads. By observing the acoustic emission activity as loads are applied it is possible to monitor the rate of internal material deterioration taking place (yielding or fracture) as a function of load. It is generally possible to determine the stage of incipient failure as this is usually accompanied by a rise in the acoustic emission rate and rapid increase in the cumulative number of emissions.

A major difficulty in interpreting acoustic emission results is the separation of signals due to the loading system or microscopic slippage at joints in the test object from the signals due to flaw propagation in the material. Users of the technique must be aware of all the possible extraneous acoustic signals that may be detected by the transducers, and must take precautions not to confuse them with signals due to flaw growth. Some background noise may be eliminated by using low frequency filters, but usually it is necessary to properly plan an acoustic emission inspection to eliminate unwanted noises. Equipment costs vary from moderate $(\$ 10,000)$ to very expensive depending on whether a single- or multiplepickup system is required for the particular application.

\section{Acoustic Impact Method}

\subsection{Description of Method}

Acoustic impact is the oldest and simplest form of acoustic inspection. In this method, audible stress waves are set up in a test object by mechanical impact and the frequency and damping characteristics of the vibrations can be used to infer the integrity of the test object [2]. In its most unsophisticated form, the test object is struck with a hammer and the operator listens to the "ringing" (which is due to resonant vibration of the object). In a more sophisticated form, a transducer is attached to the test object, and an amplifier and display unit are used to produce a visual display of the frequency and damping characteristics of the "ringing". By comparing the output with a standard of acceptable quality, a decision is made regarding the integrity of the object.

\subsection{Applications}

This method can be used to detect hollow zones and delaminations in concrete and masonry structures or it may be used to detect the location of studs behind wallboard. It also has been used to detect deliminations in laminar and composite materials and rot in wood. By measuring the transmission time in wood, it's modulus of elasticity can be determined.

\subsection{Advantages and Limitations}

The equipment required to carry out the test is relatively inexpensive and the test can be performed easily. However, because the "ringing" can be affected by the mass and geometry of the test object, an experienced operator may be needed to correctly interpret the results.

\section{Cast-In-Place Pullout}

The pullout test measures the force required to pull out a steel insert, having an enlarged end, which has been cast in concrete (fig. 1). The concrete is subject to a complex state of stresses by the pullout force, and a cone of concrete is removed at failure. The pullout forces are usually related to the compressive strength of the concrete, with the ratio of pullout strength (force divided by surface area of the conic frustum) to compressive strength being in the range of 0.1 to 0.3 . Correlation graphs are used to relate pullout force to compressive strength. There are several commmercially available test apparatus for measuring the pullout resistance of concrete with prices varying from $\$ 1000$ to $\$ 6000$.

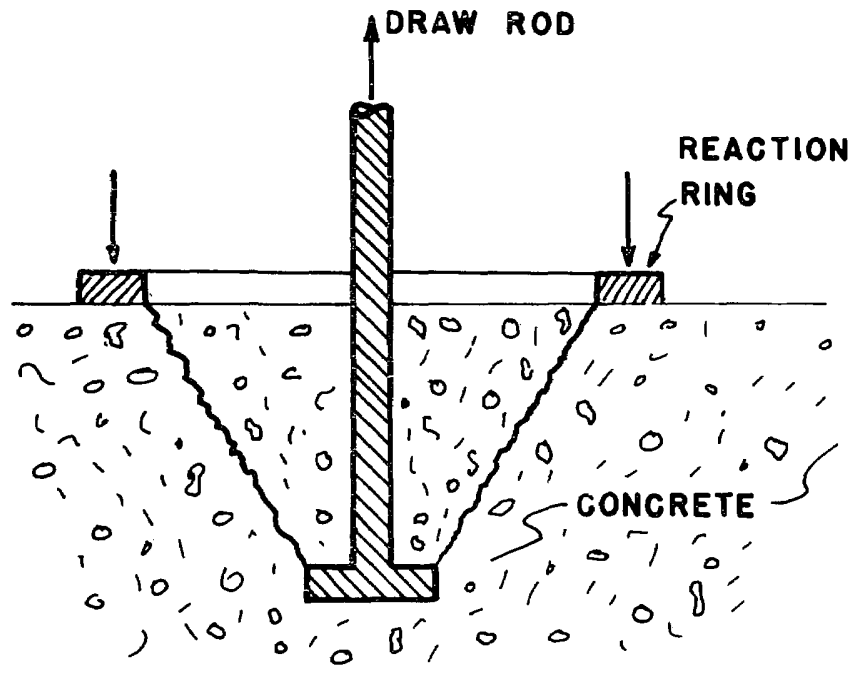

FIGURE 1. Schematic of cast-in-place pullout device.

\subsection{Description of Method}

The American Society for Testing and Materials (ASTM) has recently issued a test method, C900 [3] which describes the pullout assembly and gives allowable dimensions. The pullout insert is cast-in-place during placing of fresh concrete, and it is either pulled completely out of the concrete, or pulled until maximum load is reached, with a manually operated hollow tension ram exerting pressure through the steel reaction ring. Components of one possible test apparatus for pulling 
out the insert are shown in figure $2 . \dot{2}$ Testing and calculation procedures are also given in ASTM C900. Techniques have been developed so that the inserts can be embedded deep in concrete, thereby permitting testing of the interior concrete.

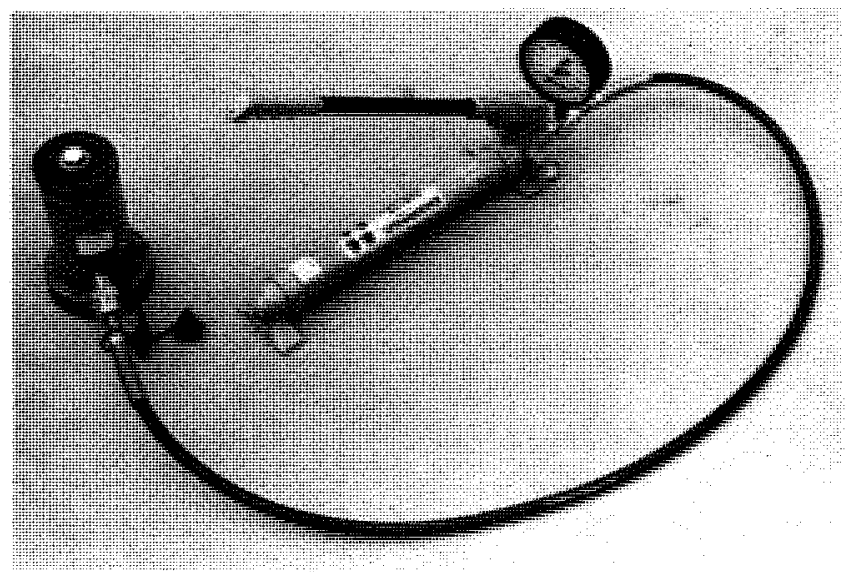

Figure 2. Components of one sype of apparatus for performing pullout test.

Because the pullout insert is usually cast-in-place during placing of the fresh concrete, these tests must be planned in advance. Alternatively, hardened concrete can be drilled to receive the pullout insert. This neccesitates drilling through the bottom or backside of a concrete slab for example, to the proper depth and width to permit the insertion of the enlarged head. A smaller hole, sufficient to permit insertion of the steel shaft, is drilled through the remaining portion of the concrete slab, the insert is placed through the bottom or backside, and the test is performed. This alternate method is currently being developed and is not covered by ASTM C900.

\subsection{Reliability of Method}

Malhotra [4] and Richards [5] have shown the pullout method is a reliable method for estimating the compressive strength of concrete. Malhotra found that the coefficients of variation for pullout test results were in the same range as those obtained from testing standard cylinders in compression. Correlation coefficients of 0.97 to 0.99 have been obtained for normal weight concrete from curve fitting of pullout and compression test results.

\footnotetext{
${ }^{2}$ In this paper several commercially available devices used for NDE tests of building materials are identified and discussed. Such identification does not imply recommendation or endorsement by the National Bureau of Standards.
}

\subsection{Advantages and Limitations}

The pullout technique is the only nondestructive test method which directly measures a strength property of concrete in place. The measured strength is thought to be a combination of tensile and shear strengths.

The major disadvantage of the pullout test is that a cone of concrete is sometimes pulled out necessitating minor repairs. However, if the pullout force is quickly released when failure is just initiated, the concrete cone will not be torn loose, and no repairs will be required. Another disadvantage is the need to plan where inserts are to be located and to make provisions for their placement prior to placing concrete. The feasibility of drilling holes into hardened concrete and inserting pullout devices is being explored [6]. This would eliminate the need to install the inserts prior to placing concrete.

\section{Electrical Potential Measurements}

Information on the corrosion state of metals can be obtained from measuring the electrical potential of the metal using a standard reference electrode and a voltmeter. As the electrical potential of a metal becomes more negative, the probability that corrosion has taken place increases.

\section{1. Measurements on Steel In Concrete}

The electrical potential method is commonly used to assess the corrosion condition of steel reinforcement in concrete. The electrical potentials of steel reinforcement are measured by making an electrical connection from a voltmeter to the reinforcement and a second electrical connection from the voltmeter to a reference cell in physical contact with the surface of the concrete (fig. 3 ). Dry concrete must be moistened before making electrical measurements. A saturated copper-copper sulfate electrode is usually used as the reference cell. The electrical potential of the reinforcement located below the reference cell is measured.

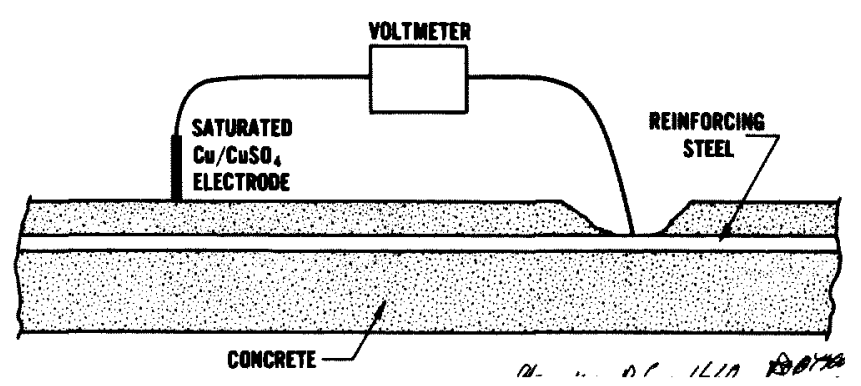

Figure 3. Measurement of electrical potential of steel reinforcing bars in concrete. 
If the electrical potential of the steel reinforcement is more negative than $-0.35 \mathrm{~V}$ versus the copper sulfate electrode, active corrosion is probably taking place. Values in the range of -0.30 to $-0.35 \mathrm{~V}$ suggest that corrosive conditions are developing at the concrete-steel interface, while values less negative than $-0.30 \mathrm{~V}$ indicate that the steel is probably passive, i.e., not corroding [7].

An electrical potential diagram of a concrete slab can be constructed in which areas of similar potentials are outlined. This can be used to identify those areas where reinforcement may be corroding.

\subsection{Advantages and Limitations of Method}

The equipment is inexpensive and only a moderate amount of user expertise is needed to make the measurements. Measurements of the electrical potential of steel reinforcement provide information concerning the probability for the occurrence of corrosion. However, information on either the rate or the extent of corrosion is not obtained. In addition, a direct electrical connection must be made to the reinforcing steel. If the steel is not exposed, then some concrete covering must be removed.

\section{Electro-Magnetic Methods}

The presence of flaws or changes in composition of metals will affect their electrical and magnetic properties. Therefore, it is possible to detect anomalies in metals by measuring changes in the electrical and magnetic characteristics of metals. NDE methods that function on the above basis include eddy current, magneto-inductive, and magnetic particle testing.

\subsection{Eddy Current Inspection}

Eddy current inspection is a versatile NDE method based upon the principles of electromagnetic induction and is only applicable to inspection of metals [1].

\subsubsection{Description of Method}

A coil carrying an alternating electric current will produce an alternating magnetic field opposing the flow of current into the coil (figure 4). When the coil is brought near a conductive material, this alternating magnetic field induces a closed-loop current flow in the material known as eddy current. The eddy currents will also be alternating, and, therefore, a secondary magnetic field is produced by them which opposes the magnetic field of the coil. Thus, when the energized coil is brought near a metal surface there will be a change in the current flow

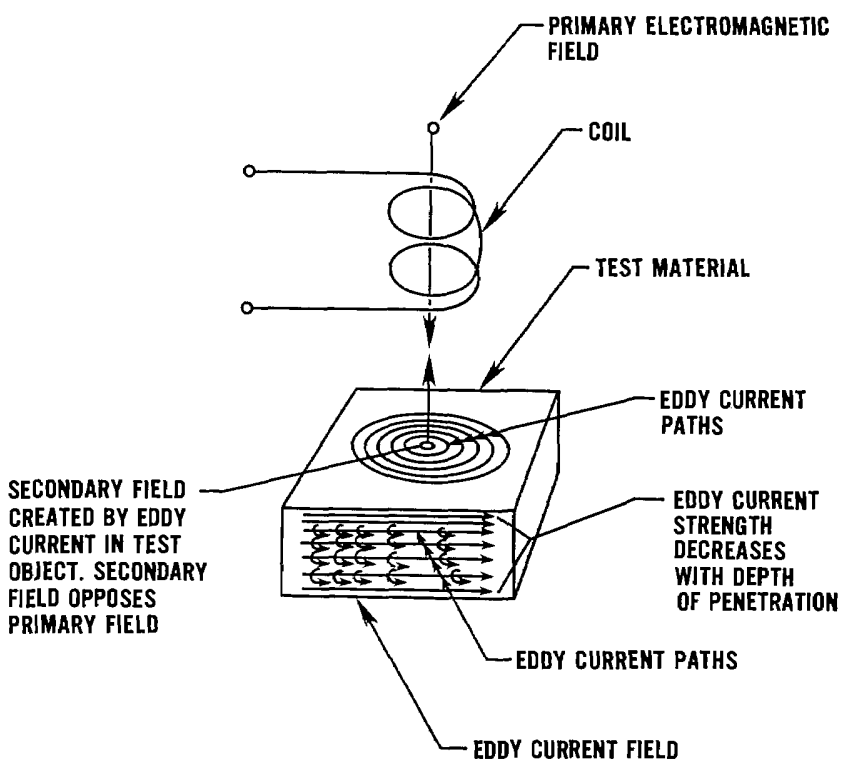

FigurE 4. Establishment of eddy currents in a metallic building material [9].

in the coil. Measuring the changes in the current flow (or the coil impedence) is the basis of eddy current inspection.

The magnitude of the change in the coil current will depend on the intensity of the eddy currents induced in the metal. Factors which influence the intensity of eddy current flow include the following [8]:

1) the frequency and magnitude of the coil current,

2) the electrical conductivity of the metal,

3) the magnetic permeability of the metal,

4) the size and shape of the test object,

5) the proximity of the coil to the test object, and

6) the presence of discontinuities or inhomogeneities in the metal.

The electrical and magnetic properties of the metal are controlled by alloy composition, microstructure and residual stresses [1].

\subsubsection{Eddy Current Inspection System}

An eddy current device consists of the following components: inspection coil, an oscillator to provide coil excitation, a detector to monitor changes in coil impedance, and an output device to display the test results. Various kinds of coil geometries are available depending on the specific application. An important principle when inspecting for discontinuities is that the maximum signal is obtained when the eddy current flow is transverse to flaw. Thus, the user needs to understand the relationship 
between coil configuration, eddy current flow and type of flaw to be detected.

The frequency of the excitation current affects the depth of the eddy currents and the sensitivity of flaw detection. Increasing the coil frequency will reduce penetration but increase sensitivity. Thus high coil frequencies should be used in attempting to detect small near-surface flaws. If it is desired to detect sub-surface flaws, a lower frequency should be used but the minimum detectable flaw size increases. Thus, there is a trade-off of penetrating ability versus sensitivity which is common to other inspection methods. The range of frequencies is from $200 \mathrm{~Hz}$ to $6 \mathrm{MHz}$ [1], with the lower frequencies used primarily for inspecting ferromagnetic metals.

The detector circuit can also take on many forms depending on the application of the instrument. In any case, the changes in coil impedance that occur during inspection are small and bridge circuitry, similar to that used to monitor electrical resistance strain gages, is used to detect these changes. In making a measurement, the impedance bridge is first balanced by using an internal adjustment or placing the coil on a reference object of acceptable quality; then the coil is placed on the test object, and any difference between test object and reference object will result in an imbalance of the bridge which is indicated on the output device. The output device can be of many forms, such as audible alarms, meters, X-Y plotters, strip-chart recorders, magnetic tape, storage oscilloscopes, or a computer.

\subsubsection{Instrument Calibration}

Because there are many factors that may affect the coil impedance when a test is performed, the object used to calibrate the instrument must be carefully chosen. For example, to detect cracks, the reference object must have the same electrical and magnetic properties as the test object; otherwise differences in alloy composition could be interpreted as a crack. Therefore, a user must be knowledgeable in the operation of an eddy current device in order to properly calibrate it and to interpret test results.

\subsubsection{Applications}

Eddy current inspection has many uses including the detection of flaws such as cracks, porosity, or inclusions in metals; detection of changes in alloy composition or microstructure; and the measurement of the thickness of nonconductive coatings on a metal.

\subsubsection{Advantages and Limitations}

There are several important limitations to eddy current inspection. A major limitation is the depth at which discontinuities can be detected. The density of eddy currents rapidly decreases with increased distances below the surface of a metal. The depth of penetration is controlled by the resistivity and permeability of the metal and the coil frequency.

The strength of the signal due to a particular defect will depend on the proximity of the coil to the surface of the test object. As this distance, called "lift-off," increases the signal strength diminishes. The lift-off effect is so strong that it may mask signal changes due to defects. Care must be taken, therefore, to ensure uniform contact between coil and test object. This requirement may make it difficult to test objects with rough or irregular surface. The lift-off effect may be used, however, in measuring the thickness of nonconductive coatings on a conductive metals or non-magnetic metal coatings on magnetic metals. Proper calibration samples are required to use an eddy current instrument as a thickness gage.

\subsection{Magneto-Inductive Methods}

This technique is only applicable to ferromagnetic metals and is primarily used to distinguish between steel of different alloy composition and different heat treatments. The principle involved is electromagnetic induction and the equipment circuitry resembles a simple transformer in which the test object acts as the "core" [1]. There is a primary coil connected to a power supply delivering a low frequency $(10$ to $50 \mathrm{~Hz}$ ) altering current, and a secondary coil feeding into an amplifier circuit. In the absence of a test object, the primary coil induces a small voltage in the secondary coil, but when a ferromagnetic object is introduced a much higher secondary voltage is induced. The magnitude of the induced voltage in the secondary coil is a function of the magnitization characteristics of the object, and changes in these characteristics are used to distinguish between samples of different properties. As in the case of eddy current inspection, this method can be used for quantitative measurement only after proper calibration is performed.

\subsection{Cover Meters}

Cover meters are portable, battery-operated magnetic devices that are primarily used to estimate the depth and location of reinforcing steel (bars and tendons) embedded in concrete. In addition, some information can be obtained regarding the dimensions of the reinforcement [4]. 


\subsubsection{Principle and Applications}

Cover meters are magnetic devices that are based on the magneto-inductive principle. A typical meter is shown in figure 5. A magnetic field is induced between the two faces of the probe, which houses a magnetic core, by an alternating current passing through a coil. If the magnetic field passes through concrete containing reinforcement, the induced secondary current is controlled by the reinforcement. The magnitude of this change in inductance is measured by a meter. For a given probe, the magnitude of the induced current is largely controlled by the distance between the steel reinforcement and the probe.

The induced current decreases as the distance from probe to the reinforcement increases because the magnetic flux intensity of a magnetic material decreases with the square of the distance. In addition, the magnetic permeability of the concrete, even though it is low, will have some affect on the reading. Therefore, the calibrated scales on the meters of commercial equipment are nonlinear. Also, a meter must be readjusted if a different probe is attached.

The probe is highly directional; i.e., a sharp maximum in induced current is observed when the long axis of the probe and reinforcement are aligned and when the probe is directly above the reinforcement.

The commercial cover meter shown in figure 5 can detect reinforcement with a concrete cover as thick as 8 inches $(200 \mathrm{~mm})$. Through the use of spacers of known thickness, the size of reinforcing between 0.38 to 2 in. 16 to $51 \mathrm{~mm}$ ) can be estimated.

Another possible application of the cover meter is to estimate the thickness of slabs which are accessible from both sides. If a steel plate is aligned on one side with the probe on the other side, the measured induced current will give an indication of the thickness of the slab. For

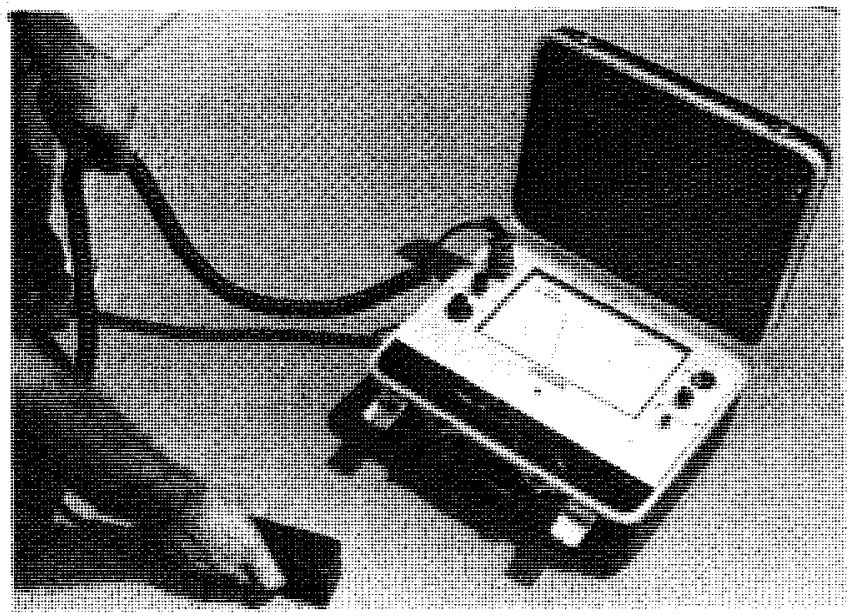

Figure 5. Cover meter used to detect steel reinforcement. this application, a series of calibration tests must be first performed.

\subsubsection{Advantages and Limitatlons}

Cover meters are portable, inexpensive, instruments that can be easily used. They are most useful when reinforced concrete has only one layer of widely separated reinforcing bars. In highly reinforced concrete, the presence of secondary reinforcement makes the determination of the depth of concrete cover difficult. Furthermore, reinforcing bars running parallel to those being measured influence the induced current if the distance between bars is less than two or three times the cover distance [4].

\subsection{Magnetic Particle Inspection}

\subsubsection{Principle of Method}

This inspection method relies on the ability of cracks to alter the magnetic field within a metal so that fine magnetic powder will be attracted to the crack zone and cracks thereby identified $[1,10,11]$. To further understand the principle, consider a bar magnet in which the magnetic field passes through the magnet from south to north poles. If ferromagnetic particles are sprinkled over the middle surface of a crack free magnet, there will be no attraction because the magnetic field lies wholly within the magnet. Now consider the case in which the magnet is cracked; the two sides of the crack will act as north or south poles, and the magnetic field bridges the gap. However, some of the magnetic field will leak out of the magnet into the surrounding air space, and ferromagnetic powder will be attracted by the leakage field. Therefore, the attraction of the powder gives an indication of the presence of the crack. A subsurface crack would also produce a leakage field, but the response would be weaker than for a surface crack of the same size.

\subsection{Application of Method}

In using the magnetic particle method, it is necessary to magnetize the object being inspected, to apply ferromagnetic particles, and then to inspect for indications of cracks. There are two general types of magnetic fields that may be induced in the test object, circular and longitudinal fields. A circular field will be produced by passing an electric current through the test object, in which case the magnetic field would be concentric with the direction of current flow. A longitudinal field will be created by placing the part inside a coil carrying electric 
current, in which case the magnetic field will be parallel to the longitudinal axis of the coil. The direction of the magnetic field relative to the test object controls which cracks will be detected. Strong leakage fields are produced by cracks which intersect the magnetic lines of force at an angle, and no leakage fields are produced by cracks parallel to the magnetic lines of force. Therefore, complete inspection of a part should involve rotation of the test object with respect to the magnetic field to make sure that all existing cracks intersect the magnetic field lines.

In field inspections, it usually is not practical to pass a current through the entire part or surround the part with a coil. Portable units are available that permit inspection of small portions of the test object at one time. For example, prods can be used to introduce a flow of current between two contact points on the object. In this case a circular magnetic field is induced. A yoke, i.e., a U-shaped electromagnet in which the poles are brought into contact with the test object, can also be used. With a yoke, a longitudinal magnetic field is set up in the object and the lines of force run from one pole to the other pole of the electromagnet. With either portable method, only a small portion of a large test object can be inspected at one time; 12 in $(300 \mathrm{~mm})$ is about the practical limit [1] for spacing between prod contacts.

The choice of current type used to magnetize the test object is important. If it is desired to detect subsurface cracks, direct current must be used because alternating current will only produce a surface magnetic field. The direct current may be from a constant or pulsating source, though the pulsating type is preferred because it imparts greater mobility to the ferromagnetic powder. The current supply is low voltage and very high amperage for user safety but still permits strong magnetization of the test object. Inspection is usually carried out with the current on but if the metal has high retentivity (permanent magnetism), the current may be turned off before applying the powder.

The powder used to indicate the leakage fields may be dry or suspended in a liquid. Dry powders are preferred for the best sensitivity to subsurface cracks and should be used with direct current while the wet powders are superior for detecting very fine surface cracks. To enhance visibility, various colors are available so that high contrast with the background can be achieved. In addition, fluorescent particles are available for increased visibility.

\subsubsection{Advantages and Limitatlons}

The magnetic particle inspection method has several advantages over other crack detection systems [1]. The equipment is portable, inexpensive, and simple to operate; positive crack indications are produced directly on the part and no electronic equipment is needed; and any shape part that is accessible can be inspected. However, there are some limitations that must be understood by the user. The method will only work with ferromagnetic metals. For complete inspection, each area needs to be inspected more than once using different magentic field directions and very large currents are needed to inspect large areas. Experience and skill is needed to properly interpret the particle indications and to recognize patterns which do not indicate cracks. Demagnetization may be required after inspecting steels with high magnetic retentivity. The maximum depth of flaw detection is about one-half inch $(13 \mathrm{~mm})$, and the minimum detectable flaw size increases as its depth increases.

\section{Leak Testing Method}

\subsection{Principle of Method}

Leak testing refers to the detection of holes in pipes and tanks which permit the escape of liquids or gases [9]. There are many different methods of leak testing but they can be generally classified into two categories. In the first category, the leaking system is monitored under normal operating conditions. This includes the use of pressure meters, the applications of a soap solution, or the use of audio or amplified listening devices. In the second category, a particular substance is added into the system flow to provide special indications of leakage. This includes such additives as colored dyes, Freon 12 , helium gas, radioactive tracers, and odorous indicators.

\subsection{Applications}

Many leak detection methods are suitable for field application. Liquid storage vessels and above ground piping can usually be checked visually for leakage under normal operating conditions with no special equipment. Gas-carrying systems can usually best be checked in the field with a soap solution or, when Freon gas is added to the system, with a propane torch. These systems have no special power requirements and none of the equipment weighs more than $5 \mathrm{lbs}(2 \mathrm{~kg})$.

\subsection{Advantages and Limitations}

Leak detection methods can locate flaws too small to be found by any other NDE method. Gas leaks with rates as small as $10^{-12} \mathrm{cc} / \mathrm{s}$ can be detected with the use of radioactive tracers and radiation monitoring devices, 
while a soapy water solution can locate leaks with rates as low as $10^{-3} \mathrm{ec} / \mathrm{s}$ [9].

Flaws can be detected only if they penetrate through a structure that can be held at pressure conditions differing from the surrounding atmosphere.

\section{Microwaves}

Microwaves are a form of electromagnetic radiation which has frequencies between $300 \mathrm{MHz}$ and $300 \mathrm{GHz}$ corresponding to wavelengths of one meter to one millimeter. Microwaves are generated in special vacuum tubes called klystrons and transported in a circuit by waveguides. Diodes are commonly used to detect microwaves.

\subsection{Applications}

Microwaves are reflected when they intercept a boundary between regions of different dielectric properties. They thus may be used for the detection of interfaces and voids. This technique can be used to detect delaminations and the presence of different materials in highway pavements [12-14]. The use of microwaves to estimate the moisture contents of roofing materials [15] and concrete [4] also has been explored. Similar to capacitance instruments (section 9) the effect of water on the dielectric properties of materials is determined. Boot and Watson [16] reported that the microwave technique only estimated the moisture content of concrete to within 12 to 30 percent of its mean value. Its low accuracy was largely attributed to the heterogeneity of concrete, and the internal scattering and diffraction it caused.

\subsection{Limitations}

The feasibility of using microwaves for inspecting installed construction materials has not been demonstrated. Further development work is required if the microwave method is to become a reliable field NDE method.

\section{Moisture Detection Methods}

Many of the problems encountered in a building are attributed to the presence of moisture. Visual inspection can reveal surface moisture, but even if a surface is dry, subsurface moisture can be present. Therefore, NDE methods are often used when making moisture inspections. Four NDE methods are commercially employed in moisture inspections: electrical resistance measurements; capacitance instruments; nuclear meters; and infrared thermography $[15,17,18]$.

\subsection{Electrical Resistance Probe}

\subsubsection{Principle and Applieatlons}

The resistance probe method involves the measurement of the electrical resistance of a material, which decreases as the moisture content increases. Most instruments consist of two closely spaced probes and a meter-battery assembly which are enclosed in one housing or in two attached assemblies. A commercial instrument is shown in figure 6 . The probes are usually insulated except at the tips so that the region being measured lies between the tips of the probes. The probe can penetrate soft materials, such as roofing membranes, so that moisture located at various distances below the surface can be detected. Operation of a resistance probe is very simple. A voltage is impressed between the probes and the resistance is measured.

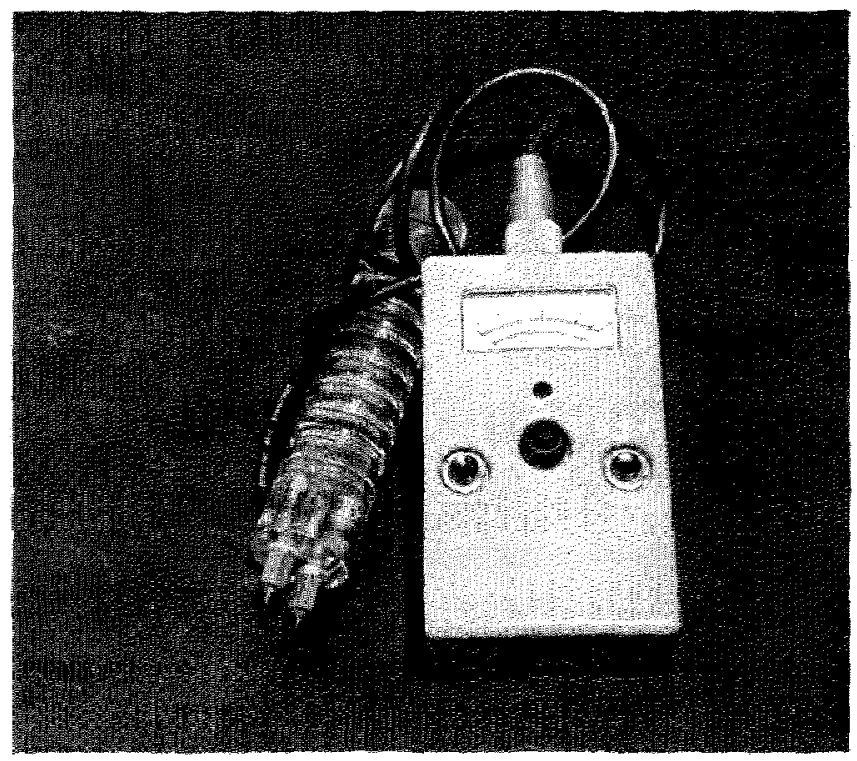

FIGUnE 6. Electrical resisance instrument for detecting moisture.

Probe instruments have been used for moisture detection in plaster, brick, concrete and roofing materials. Similar procedures have been used for determining the electrical resistance of soils. In this application a 4-probe system is used.

\section{B.1.2. Callbration}

The electrical resistance probe instruments and other moisture measuring instruments are nsually calibrated by abtaining relationships between their response and the moisture content of materials similar to those being inspected. The moisture contents of the specimens are gravimetrically determined, i.e., specimens are weighed 
before and after oven drying with the differences in weight giving their moisture contents.

\subsubsection{Advantages and Limitations}

Electrical resistance probe instruments do not give a precise determination of moisture contents. The simple inexpensive instruments, while giving only a qualitative indication of wetness, are useful in identifying wet areas and for determining moisture migration patterns. More sophisticated instruments appear to be capable of giving semi-quantitative information if they are properly calibrated.

\subsection{Capacitance Instruments}

\subsubsection{Principle and Applications}

Capacitance instruments used to detect moisture are based on the principle that moisture can affect the dielectric properties of a material [17]. The dielectric constant, $K$, of a material is a relative measure of the ability of a material to store electrical energy and is given by:

$$
\mathrm{K}=\mathrm{C} / \mathrm{Co}
$$

where $C$ is the capacitance of a material and $\mathrm{C}_{o}$ is the capacitance of vacuum.

The dielectric constants for many dry building materials are usually low, e.g., for dry roofing materials $K$ ranges from 1 to 5 , while water has a $K$ of approximately 80 [17]. The value of $K$ for a moist material will increase linearly as the volume fraction of water increases. Capacitance radio frequency instruments have been used to measure the moisture contents of paper products, wallboard, and roofing materials. Commercial capacitance instruments have various electrode configurations. The electrodes are attached to a constant frequency alternating current source and they establish an electrical field in the material being tested. Current flow or power loss is then measured which is indicative of moisture content. Most instruments operate in the radio frequency region of 1 to $30 \mathrm{MHz}$.

\subsubsection{Advantages and Limitations}

Capacitance instruments are portable and measurements can be taken rapidly. A recent investigation by Knab et al. [18] suggests that capacitance instruments may not give reliable quantitative measurements of the moisture contents of roofing systems. Further work appears required to establish the reliability of using this method for moisture measurements of building materials.

\subsection{Nuclear Meters}

\subsubsection{Principle of Method}

Fast neutrons, emitted during the decay of radioactive isotopes, are used in making moisture content measurements $[16,17]$. Fast neutrons from the isotope source enter the material and are both scattered and slowed down by collision with the nuclei of the atoms composing the material (fig. 7). Nuclei of all materials slow down the neutrons by momentum exchange, but the reduction is greatest for collisions with hydrogen nuclei which have about the same mass as the neutrons. Some

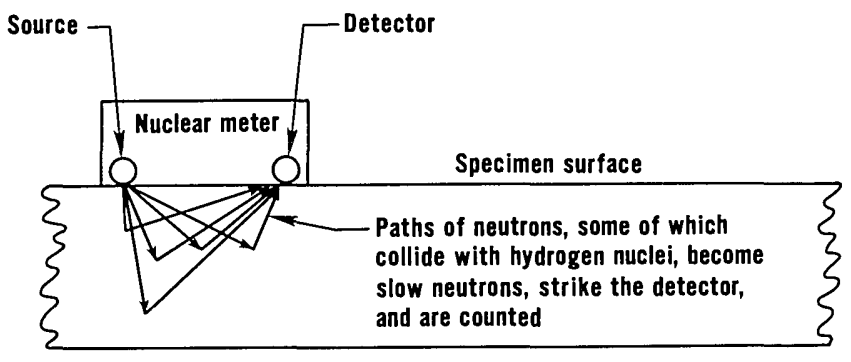

Figure 7. Process by which a nuclear meter detects moisture.

of the slow or thermal neutrons, are scattered in such a way that they reach the slow neutron detector in the instrument and are counted for a specified period of time. The thermal neutrons reaching the detector are much more likely to have collided with hydrogen nuclei than other atomic nuclei because the scattering cross-section of hydrogen is greater than that for other atoms. Thus, the method is capable of detecting moisture content. The detector largely measures the backscattering of slow neutrons which have collided with hydrogen nuclei in the surface region of the materials. For example, the depth of measurement is limited to between 2 to 8 in (51 to 203 $\mathrm{mm}$ ) in soils.

\subsubsection{Commercial Meters and Applications}

Nuclear meters (fig. 8) are used to measure both moisture content and density of soils, portland-cement concrete, asphaltic concrete, and roofing materials [4, 15]. These meters consist of a shielded radioactive isotope source, a detector or counting device, and readout equipment. In commercial meters, the isotopes used are radium 226-beryllium, and americium 241beryllium. Both americium and radium are alpha particle emitters and these particles interact with the nuclei of beryllium resulting in the emittance of fast neutrons.

In addition to neutron sources, most commercial nuclear moisture meters also have gamma ray sources. 


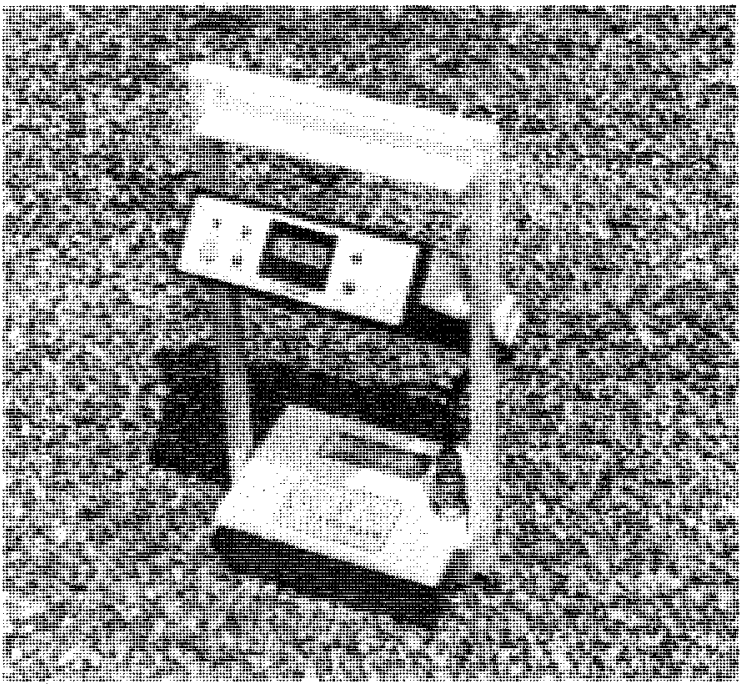

Figune 8. Nuclear meter used to measure moisture contents of materials.

The gamma rays are used to determine the density of materials. See section 13 for explanation of the principle.

\subsubsection{Adventages and Limitations}

Nuclear meters are portable and moisture measurements can rapidly be made on materials. However, the hydrogen atoms of building materials in addition to those of water will contribute to the number of detected thermal neutrons. For example, asphalt in a roofing membrane may contribute to a reading because it contains bonded hydrogen atoms. For hydrogencontaining materials, calibration of the meter is required using samples identical to those expected during field inspection. Also, a license must be obtained from the Nuclear Regulatory Commission for domestic use of the radioactive isotopes in the neutron source of the neutron moisture meters.

\subsection{Infrared Thermography}

In addition to detecting heat loss, infrared thermography can be used to detect moisture in building materials if heat is flowing through them. The presence of moisture will effect the heat transfer properties of materials which permits the identification of wet areas by thermography. The principle involved in making hermography scans is discussed in section 16. This method is being used in making aerial scans of roofs, whereby large roof areas and many buildings can be scanned in a relatively short time [15]. Hand held inrared cameras also are being used to measure heat losses Ind to detect moisture in roofing systems [19]. See sec- tion 16 for additional applications of this method.

In using the thermography method to detect moisture in roof systems, it is necessary to assume that temperature gradients are caused by moisture and are not associated with differences in roofing composition or thickness. Because construction and thickness variations can be present, results from thermographic inspections should be interpreted carefully.

\section{Paint Inspection Gage (Tooke Gage)}

\subsection{Principle and Applications}

The paint inspection gage is used to measure dry paint film thickness by the microscopic observation of a small $V$-groove cut into the paint film. In addition, the number of paint layers and their individual thickness can be determined. The thickness of dry coating applied to any type of surface (e.g., wood, metal, glass, or plastic) can be measured. A commercially available paint inspection gage, the Tooke Gage, is shown on figure 9. This gage is portable having overall dimensions of $4.5 \times 3.5 \times 1$ in (114 $89 \times 25 \mathrm{~mm})$ and weighing $26 \mathrm{oz}$. $(.74 \mathrm{~kg})$. Three cutting tips are furnished permitting the measurement of film thickness up to 50 mils $(1.3 \mathrm{~mm})$.

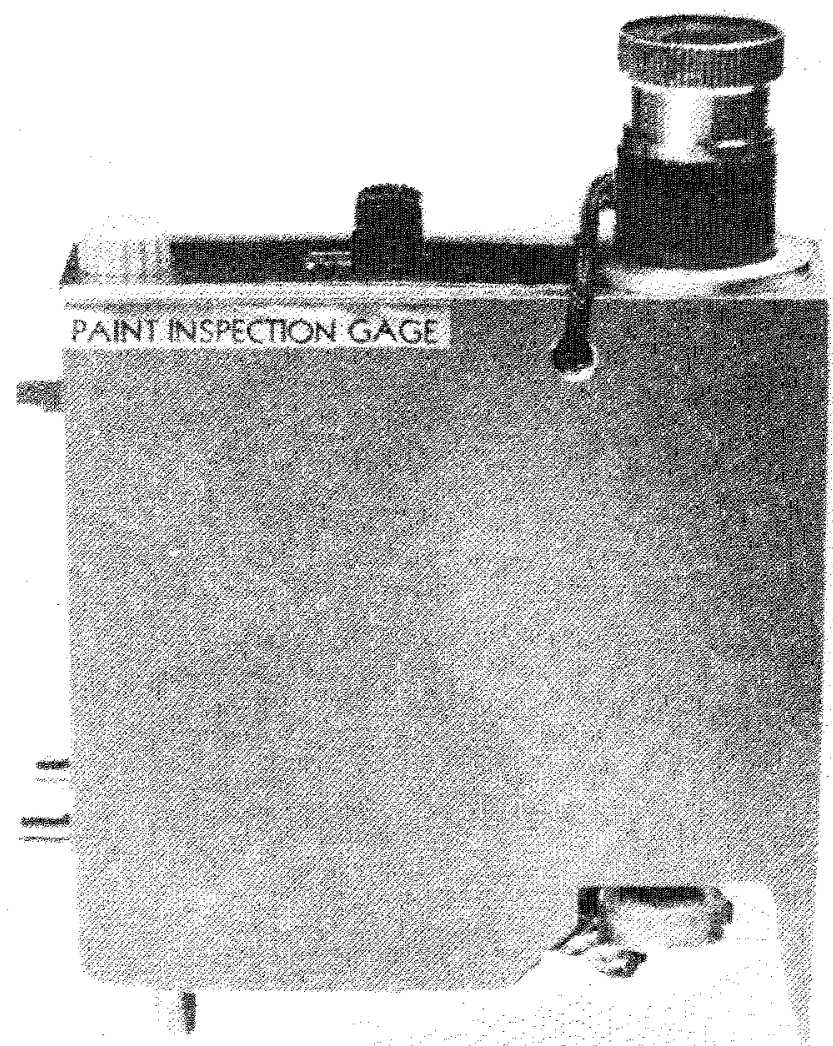

FIGURE 9. Tooke gage for measuring the thicknesses and/or number of paint layers. 


\subsection{Limifations}

A disadvantage of this method is that a cut is made in the paint film which may need to be repaired, depending on the substrate and the severity of the environment.

\section{Pin Hole Detector}

\subsection{Princlple and Applications}

A pin hole, or holiday detector, is used to determine the existence and location of pin holes (holidays) in nonconductive coatings applied to metals. Most commercial instruments consists of a probe or electrode which makes contact with the coating through a moist sponge and an earth lead such as an alligator clip (fig. 10) which is attached to an area of bare metal. When the moist sponge passes over a pin hole, an electrical circuit is completed which activates an audible alarm. Most detectors use a dc power source in the range of 9 to $67.5 \mathrm{~V}$.

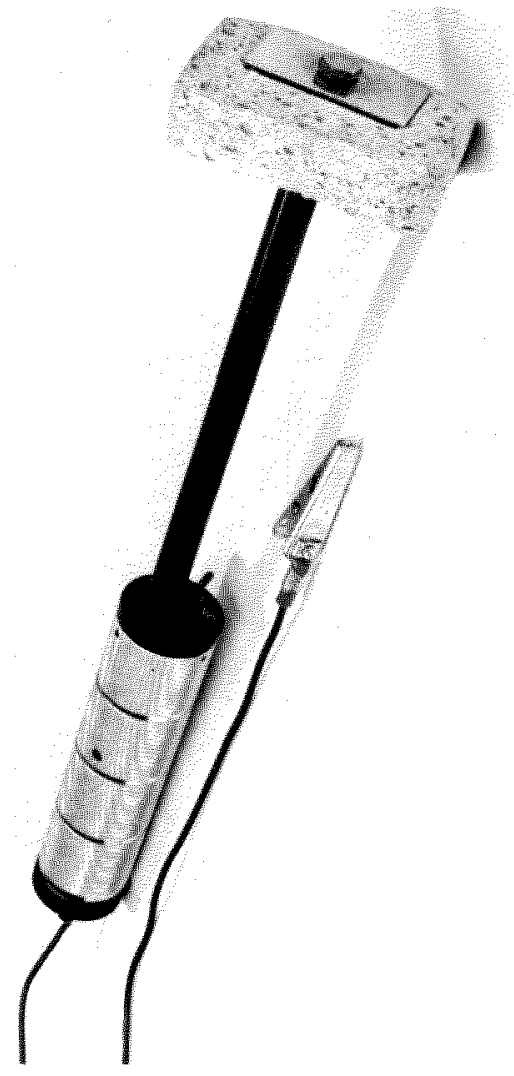

FIGURE 10. Device to inspect nonconductive coatings on metals for pin holes.

\subsection{Advantages and Limitations}

A large area can be rapidly surveyed for pin holes with this type of detector. Several problems can be en- countered however, using this type of detector. If the metallic test object is completely coated so that a bare area does not exist, a portion of the coating must be removed so that the earth lead can make contact with the metal. Pin holes can be induced in weakened areas of a coating if high voltage (approximately $10 \mathrm{KV}$ ) detection is used. The results are quantitative, since no information on the size of a pin hole is obtained.

\section{Proof Load Testing}

\section{II.1. Principle of Method}

Proof load testing is based on the concept that a structural component or structure capable of surviving the stresses of a severe loading should be serviceable under normal operating conditions [9]. Proof loading requires the ability to overload a structure in a load pattern similar to operating conditions (e.g., high pressure in a pipeline).

\subsection{Applications}

Proof load testing can be used in conjunction with leak testing (section 6) in pressure vessels and pipeline inspection leak detection sensitivity levels. This method is usually used as a last resort to determine the adequacy of a structural system.

\section{1.3. Advanfoges and Limitations}

An entire structure can be tested in its "as-built" condition. However, the test may either cause the premature failure or the destruction of a structure. Proof load testing requires extensive planning and preparation, and is usually expensive.

\section{Probe Penetration Method}

\subsection{Principle of Method}

The probe penetration method is based on measuring the non-penetrating length steel probe which partly penetrates concrete when driven by a powder charge. This method is useful for assessing the quality and uniformity of concrete in situ, and for delineating areas of poor quality or deteriorated concrete in structures.

Probe penetration results have also been used to estimate the compressive strength of concrete by using correlation graphs. The graphs are constructed by plotting the exposed lengths of probes versus experimentally measured compressive strengths. This can be done by performing penetration tests on a concrete slab and taking core samples for compressive testing. 


\subsection{Probe Equipment and Use}

The Windsor Probe is the most commonly selected, and possibly the only commercially available apparatus in the U.S. for measuring the penetration resistance of concrete. It consists of a special driving gun (fig. 11) into which a high-strength steel probe is inserted. This probe is driven into the concrete by firing a charge la 32 caliber blank with a precise quantity of powder). A series of three measurements is made in each area using the spacer plate shown in figure 12 . The length of a probe extending from the surface of concrete can be measured using a simple device as shown in figure 13 .

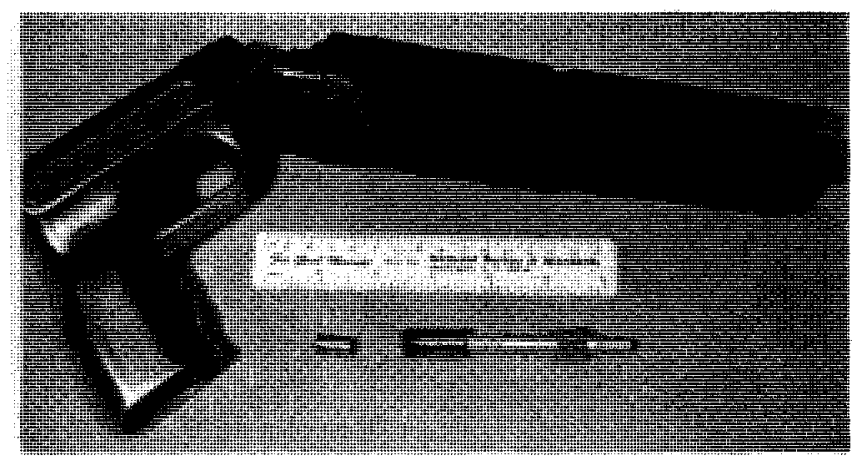

Figure 11. Windsor probe apparatus showing the gun, probe and blank cartridge.

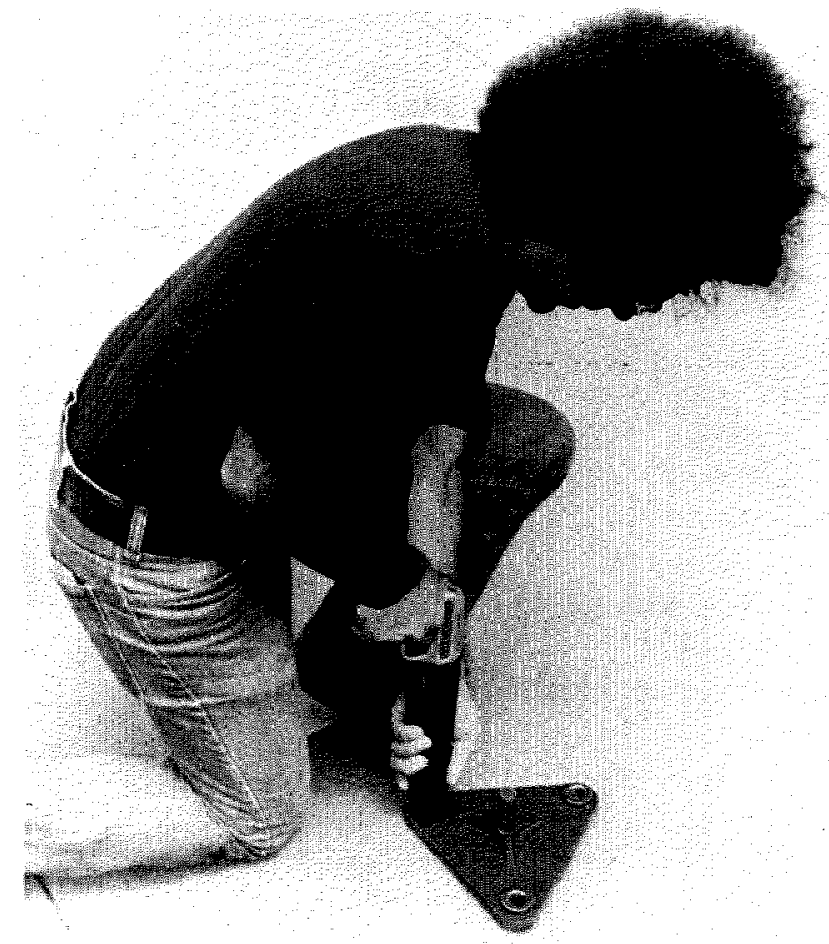

Figure 12. Windisor probe in use.

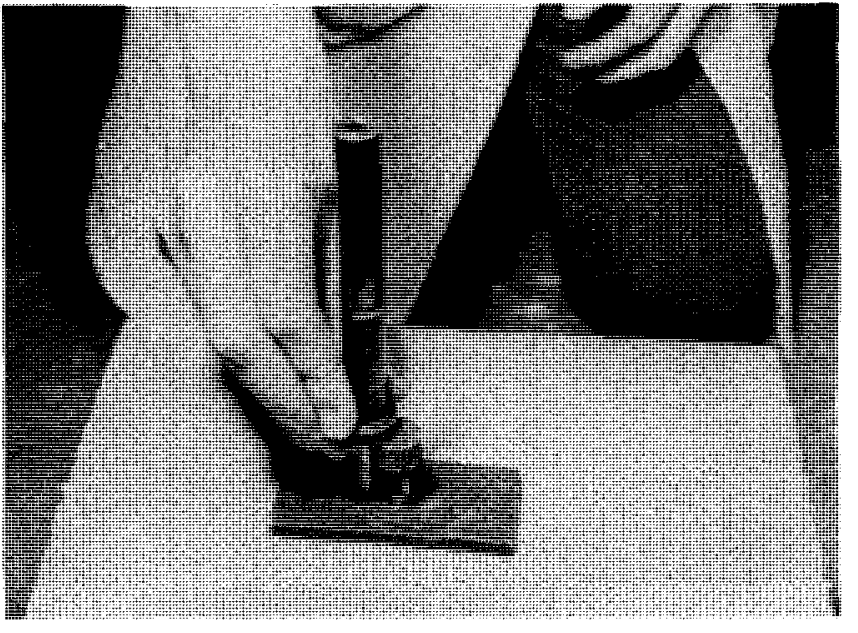

FIGUnE 13. Device for measuring length of probe extending from Burface of concrete.

Operating procedures for the Windsor Probe are given by the manufacturer. In addition, testing procedures are given in ASTM Standard C803 [20]. The probe can be easily operated by concrete inspectors, and is readily portable.

The manufacturer supplies a set of five calibration curves, each curve corresponding to a specific Moh's hardness for the coarse aggregate used in the concrete, by which probe measurements can be converted to compressive strength values. However, Arni [21] observed that use of the manufacturer's calibration curve often results in grossly incorrect estimates of the compressive strength of concretes. Therefore, it is recommended that the Windsor Probe should be calibrated by the individual user, and should be recalibrated whenever the type of aggregate or the concrete propagation is changed.

\subsection{Applicotions}

The Windsor Probe can be used for assessing the quality and uniformity of concrete because physical differences in concrete will affect its resistance to penetration. A probe will penetrate deeper as the density, subsurface hardness, and strength of the concrete decreases. Areas of poor concrete can be delineated by making a series of penetration tests at regularly spaced locations.

The Windsor Probe has been used to estimate the compressive strength of concrete. However, the relationship between the depth of penetration of the probe and the compressive strength can only be obtained empirically because penetration of the probe depends on a complex mixture of tensile, shear, and compressive forces [21]. The estimation of compressive strengths with the Windsor Probe, therefore, must be made using a correlation diagram with appropriate confidence limits. 
The probe technique appears to be gaining acceptance as a practical NDE method for estimating the compressive strengths of concrete. Improved correlations between probe results and in-place strength can be obtained by keeping the curing conditions of the test specimens close to those expected for the in-place concrete and by making sure that the test concrete is representative of the in-place concrete. If the Windsor Probe is calibrated using concrete specimens taken from an early construction stage, the calibration chart could be used to estimate the strength of concrete placed during later stages (assuming that the concrete design is the same).

\subsection{Advantages and Limitations}

The Windsor Probe equipment is simple, durable, requires little maintenance, and can be used by inspectors in the field with little training. Care must be exercised, however, because a projectile is fired and safety glasses should be worn. The gun can only be fired when it is pushed against a special spacer plate.

The Windsor Probe primarily measures surface and subsurface hardness and does not yield precise measurements of the in situ strength of concrete. However, useful estimates of the compressive strength of concrete may be obtained if the probe is properly calibrated. The probe test is very useful in assessing the general quality and relative strength of concrete in different parts of a structure.

The Windsor Probe test does damage the concrete, leaving a hole of about 0.32 in $(8 \mathrm{~mm})$ in diameter for the depth of the probe and, also, may cause minor cracking and some surface spalling, necessitating minor repairs.

\section{Radiography}

Radiography enables the inspection of the internal structure of a test object through the use of penetrating radiation, which may be electromagnetic ( $X$-ray, gamma rays, etc.) or particulate (neutrons) $[1,22,23]$. The object is exposed to a radiation beam and the intensity of the radiation passing through the object is reduced according to variations in thickness, density and absorption characteristics of the object. The quantity of radiation passing through the object is measured and used to deduce the internal structure of the test object. The types of radiation that have been most widely used are $\mathrm{X}$-rays and gamma rays, with gamma rays being most commonly used during field inspections.

\subsection{X-rays}

$\mathrm{X}$-rays are produced by bombarding a target material with fast moving, high energy electrons. The high energy electrons collide with electrons in the target, which are promoted to higher energy levels. $X$-rays are emitted as electrons fill the vacancies left by the promoted electrons. The generation of $\mathrm{X}$-rays takes place in an evacuated chamber ( $X$-ray tube) in which high energy electrons are generated by applying a very high voltage between an incandescent filament (the electron source) and the target material. By varying the voltage, $X$-rays with different penetrating abilities can be generated. For example, $200 \mathrm{kV}$ (kilovolt) $\mathrm{X}$-rays are capable of penetrating about 1 in $(25 \mathrm{~mm})$ of steel, while $400 \mathrm{kV} \mathrm{X}$ rays can penetrate up to 2 in $(51 \mathrm{~mm})$ of steel [1], which is about the maximum attainable with portable equipment. In general, the penetrating ability of $\mathrm{X}$-rays of a given energy level decreases as the density of the object increases. Portable gamma radiography units are available with greater penetrating capabilities than portable $X$-ray units. Therefore, gamma radiography is more commonly used for field inspections.

\subsection{Gamma Rays}

Gamma rays are physically indistinguishable from $X$ rays, the primary difference is the source. Gamma rays are the results of radioactive decay of unstable isotopes, and as a result there are some basic differences between gamma ray and $X$-ray radiography. Because gamma rays are due to nuclear disintegrations, a gamma ray source will lose its intensity with time and longer exposure times may be required for adequate inspection. In addition, each source produces rays of fixed penetrating ability. Isotopes of thulium, iridium, cesium, radium and colbalt have been used for radiography. Thulium has a penetrating ability of $1 / 2$ in $(13 \mathrm{~mm})$ of steel, while cobalt produces gamma rays capable of penetrating up to 9 in $(230 \mathrm{~mm})$ of steel. The gamma sources usually used for inspecting concrete are given in table 1.

Note that the relative penetration abilities of the gamma rays are controlled by their energies.

\subsection{Principle and Applications}

Gamma or $X$-ray radiation is attenuated (reduced) when passing through materials. The extent of attenuation is dependent on the density and thickness of material, and on the energy of the rays. In radiography, differences in radiation attenuation produced by variations in the density and thickness of a material are 


\begin{tabular}{|c|c|c|c|c|}
\hline $\begin{array}{l}\text { Radioactive } \\
\text { Source }\end{array}$ & $\begin{array}{c}\text { Gamma } \\
\text { Energy } \\
(\mathrm{MeV})\end{array}$ & $\begin{array}{c}\text { Half-life } \\
\left(t_{1 / 2}\right)\end{array}$ & $\begin{array}{c}\text { Optimum Working } \\
\text { Thickness of } \\
\text { Concrete (mm) }\end{array}$ & $\begin{array}{l}\text { Dose } \\
\text { Rate }^{8}\end{array}$ \\
\hline Iridium 192 & $\begin{array}{c}0.296 \\
\text { and } \\
0.613\end{array}$ & 70 days & $30-200$ & 0.55 \\
\hline Cesium 137 & 0.66 & 33 years & $100-300$ & 0.39 \\
\hline Colbalt 60 & $\begin{array}{r}1.17 \\
\text { and } \\
1.33\end{array}$ & 5.3 years & $150-450$ & 1.35 \\
\hline
\end{tabular}

aRoentgens per hour per curie at $1 \mathrm{~m}$. One curie is equal to $3.7 \times 10^{10}$ disintegrations per second.

recorded on photographic film. For example, when reinforced concrete is radiographically inspected, steel reinforcement attenuates the radiation more than concrete and appears as a lighter area in the film. Voids and cracks in the concrete will appear as darker areas on the film due to less attenuation of the incident radiation.

In practice, penetrating rays generated by a suitable source are allowed to pass through materials, with emerging radiation being recorded on $\mathrm{X}$-ray film held in a light-tight cassette. Some of the applications of gamma radiography are inspection of concrete to locate reinforcing bars, and to determine if excess porosity or voids are present [24]; inspecting welds for cracks, voids, and slag inclusion; and inspecting masonry walls for the presence of reinforcement or grout.

\subsection{Advantages and Limitations}

Radiography provides a method for readily characterizing the internal features of an in-place material or building component. This method is applicable to a variety of materials. Portable gamma radiography units can have greater penetrating abilities than portable $X$-ray units.

The most important drawback of radiography is the health hazard associated with the penetrating radiation. A radiographic inspection program should be planned and executed by individuals who have been trained and are qualified to perform this type of inspection. All personnel involved in radiographic inspection must carry devices that monitor the radiation dosage to which they have been exposed and must be protected so that the dosage rate does not surpass Federal limits. Gamma ray sources are inherently hazardous because they emit rays continuously and high energy sources have extremely high penetrating ability. As a result, gamma ray sources require large amounts of shielding material which limits the portability of gamma radiography equipment. The use of gamma ray producing isotopes is closely controlled by the Nuclear Regulatory Commission, and a license is required to use them.

\section{Seismic Testing}

\subsection{Principle of Method}

Seismic testing is the evaluation of material integrity by analysis of shock wave transmission rates and effects [9]. An array of sensing devices around an explosive charge of known energy (the most common shock load input system) is used to record shock wave transmission rates. These shock wave transmission rates can be related to material densities. Vibrational patterns induced from shock loading can be used to determine resonant frequencies in structures.

\subsection{Applications}

Seismic testing can measure soil densities and locate density variation boundaries (figure 14). Soil density
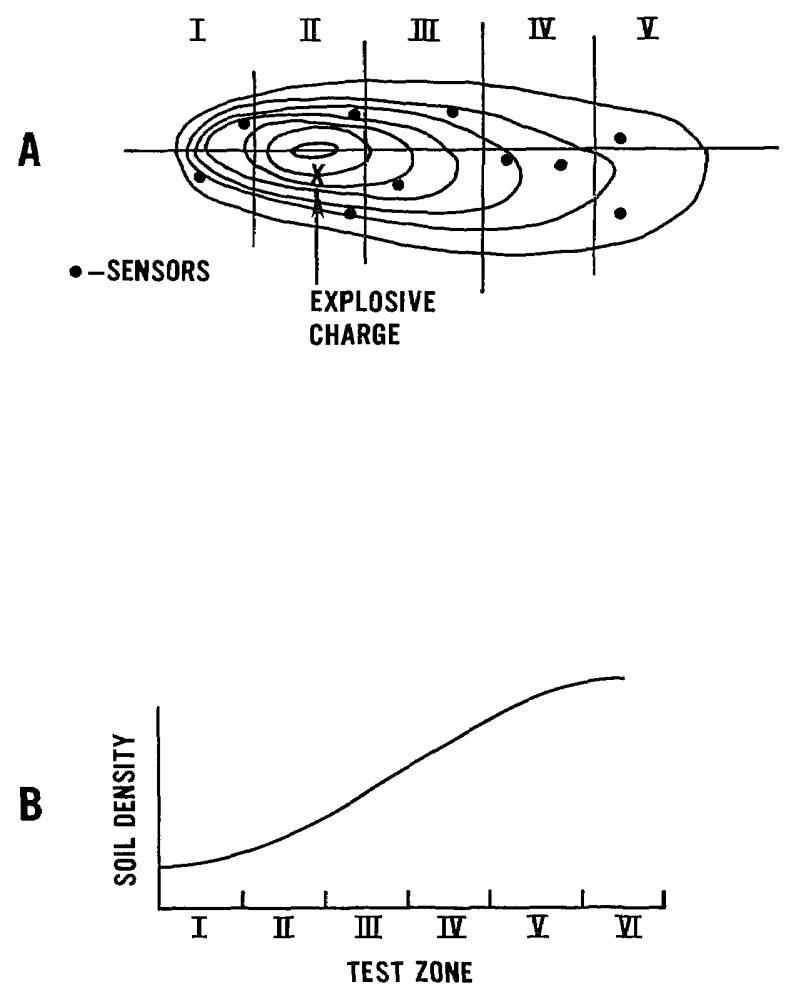

FIGURE 14. Schematic of seismic testing [9]
$\begin{array}{ll}\text { (A) Shock wave pattern } & \text { (B) Seismic test data plot }\end{array}$ 
values can then be related to load bearing capacities and foundation preparation requirements. Seismic testing can also be used to check structures for possible resonant frequencies that could cause failure under operating dynamic loads.

\subsection{Limitations}

Seismic testing is applicable only to monitoring soil conditions and structural vibrations. Multi-channel recording systems, power cables, and a large number of sensing devices are required for seismic testing. The hazards of explosives are also involved in the testing, but all components of a seismic test system are portable.

\section{Surface Hardness Testing}

Surface hardness methods are generally used to obtain an indication of the strength level or quality of a material rather than for flaw detection. Hardness in these tests refers to the resistance a material offers to indentation by an object. Indentation is produced under static or impact loading conditions; and the most common applications are in testing metals and concrete.

\subsection{Static Indentation Tests}

These methods are primarily used in testing metals. They commonly involve indenting the surface with an indentor of fixed geometry under specified loads [1]. The indenter has a small point and thereby produces high stresses in the metal at the point of contact. The stresses are sufficient to cause the metal to yield beneath the indenter and a permanent indentation results. The magnitude of the indentation will depend on the strength of the metal, the applied load, and geometry of the indenter. Therefore, by measuring the size of the indentation under a given set of conditions, an estimate of strength can be obtained.

\subsubsection{Standard Methods}

There are three widely used standard methods for hardness testing metals. The Brinell method [1] involves applying a constant load $(500,1500$ or $3000 \mathrm{~kg})$ on a 0.4 in $(10 \mathrm{~mm})$ diameter hardened steel ball-type indenter and measuring the diameter of the indentation on the test piece with a microscope. A hardness number is determined by substituting the values of the applied load, ball diameter, and indentation diameter into a standard formula. An example of a Brinell test result would be $400 \mathrm{HB}$, in which 400 is the number calculated from the standard formula, " $\mathrm{H}$ " stands for hardness and "B" for Brinell. For weaker metals a smaller load would be used to produce the indentation.

The Vickers method [1] is similar to the Brinell method except that a square-based pyramidal diamond indenter is used and the applied loads are much smaller. The diagonal of the square indentation is measured, and its value and the applied load are substituted into a standard equation to calculate the Vickers hardness number (HV).

The most common method is the Rockwell hardness test [1]. In this method the depth of additional permanent indentation that occurs as the load is increased from a small load to the test load is measured. The test instrument measures the depth automatically and the hardness number is read directly from a scale on the instrument. The Rockwell test can be performed much faster than the previously described methods. There are five different indenters and three different test loads that can be used; therefore, there are 15 different Rockwell hardness scales. For example, the result $60 \mathrm{HRC}$ indicates a hardness number of 60 on the Rockwell $C$ scale. The variety of scales permits testing a wide range of metals from very soft (weak) to very hard (strong).

\subsubsection{Usefullness of Static Tests}

Tables are available that permit conversion of the hardness number from one test method to the equivalent number of another test method (for example, ASTM E140)[25]. Tables are also available giving approximate tensile strengths of metals corresponding to the different hardness numbers. Care must be exercised in using the strength tables, because each is applicable to only certain types of metals.

Portable hardness testers are available for in-place testing of metal structures.

\subsection{Rebound Hammer Method}

The rebound method is based on the rebound theories of Shore [26]. He developed the Shore Scleroscope method in which the height of rebound of a steel hammer dropped on a metal test specimen is measured. The only commercially available instrument based on the rebound principle for testing concrete is the Schmidt Rebound Hammer [27].

The Schmidt Rebound Hammer has gained wide acceptance by researchers and concrete inspectors and is one of the most universally used nondestructive test methods for determining the in situ quality of concrete and for deciding when forms may be removed. Standards [28] have been drafted in Poland and Romania for the Rebound Hammer. The British Standards Institu- 
tion has issued Building Standard 4408 which covers nondestructive test methods for concrete, and includes the rebound hammer method in part 4 of the Standard [28]. Recently, ASTM issued Standard C805, Test for Rebound Number of Hardened Concrete, which gives procedures for the use of the rebound hammer.

\subsubsection{Description of Method}

The Schmidt Rebound Hammer consists of a steel weight and a tension spring in a tubular frame (figure 15). When the plunger of the hammer is pushed against the surface of the concrete, the steel weight is retracted against the force of the spring. When the weight is completely retracted, the spring is automatically released, the weight is driven against the plunger and it rebounds.

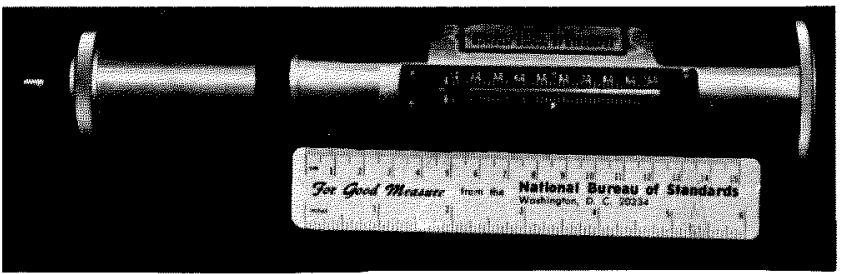

FigURE 15. Schmidt rebound hammer.

The rebound distance is indicated by a pointer on a scale that is usually graduated from zero to 100 , and the rebound readings are termed $R$-values. The determination of the R-values is outlined in the manual supplied by the manufacturer. R-values give an indication of the hardness of the concrete with values increasing with the hardness of the concrete.

Each hammer is furnished with a calibration chart, showing the relationship between compressive strength of the concrete and rebound readings based on data from tests conducted by the Swiss Federal Materials Testing and Experimental Institute. Users should not place too much confidence on the calibration chart, however, as they should develop their own for each concrete mix and for each rebound hammer.

\subsubsection{Applications}

Numerous investigators [29-31] have shown that there is some correlation between compressive strength of concrete and the hammer rebound number. Extensive disagreement exists, however, (e.g., Refs [32] and [33]) concerning the accuracy of the strength estimates from rebound measurements. Mitchel and Hoagland [34] found that the coefficient of variation for estimated compressive strength, for a wide variety of specimens from the same concrete, averaged 18.8 percent. Arni [21] found that the rebound hammer gave a less reliable estimate of compressive strength than the Windsor Probe.

Several investigators $(33,35]$ have attempted to establish correlations beteen the flexural strength of concrete and the hammer rebound number. Relationships similar to those obtained for compressive strengths were obtained, except that the statistical variations were even greater.

Mitchel and Hoagland [34] attempted to correlate rebound numbers with the modulus of elasticity of the concrete specimens. They concluded that no valid correlations could be made. Peterson and Stoll [29] and Klieger [36] have developed some empirical relations between the dynamic modulus of elasticity and hammer rebound.

The rebound hammer, like the Windsor Probe, is very useful in assessing the general quality of concrete and for locating areas in which poor quality concrete is located. A large number of measurements can be rapidly taken so that large exposed areas of concrete can be mapped within a few hours.

\subsubsection{Advantages and Limitations}

The rebound hammer provides a simple and quick method for the nondestructive testing of concrete in situ. The equipment is inexpensive, costing less than $\$ 1000$, and can be operated by field personnel with a limited amount of instruction.

The rebound hammer, however, has recognized limitations. The rebound measurements on in situ concrete are affected by $[4,33,37]$ :

(1) Smoothness of the concrete surface

(2) Moisture content of concrete

(3) Type of coarse aggregate

(4) Size, shape and rigidity of specimen, e.g., a thin wall or beam

(5) Carbonation of the concrete surface.

The rebound method is largely an imprecise test and it does not provide a reliable prediction of the strength of concrete. The rebound hammer, however, is very useful in the rapid assessment of the relative quality of concrete and for estimating the relative strength of concrete.

\section{Thermal Inspection Methods}

The presence of discontinuities in an object, such as cracks, voids or inclusions, will change the heat transfer characteristics of the object. Thus, if is a transient heat flow condition exists, there will be nonuniform surface temperatures, and the pattern of the surface temperatures can be used as an indirect indicator of sub- 
surface anomalies [1]. Thermal inspection can also be used to detect anomalous operating characteristics of a system, such as over loaded electrical wiring or heat loss through walls and roofs of buildings. The following discussion will address primarily the application of thermal inspection to detect anomolies in the internal structure of test objects such as structural metallic components and roofing systems.

\subsection{Principles of Thermal Inspection}

To establish the conditions for thermal inspection, a heat flow situation must exist or be created. If necessary, this can be done by applying a temporary heat source to the front or back surface of the test object. The flow of heat from the warm to the cold surface will be affected by the thermal diffusivity of the material which is itself a function of its thermal conductivity, density, and specific heat. If discontinuities are present which have thermal diffusivities that differ from the bulk material, local "hot" or "cold" spots will exist on the surfaces directly over the location of the voids. Therefore, by measuring the pattern of surface temperatures under heat flow conditions, subsurface flaws can be detected.

Detection of surface temperatures can be accomplished by two methods: (1) contact inspection methods, and (2) non-contact inspection methods. With contact methods, the surface is covered with a temperature sensitive material and differences in surface temperature are recorded as a pattern of the coating material. Examples of coatings that have been developed for this application are [1]: heat sensitive paints and papers; phosphor coatings whose fluorescence under ultraviolet light is affected by temperature; melting point coatings which melt when a specific temperature is reached; and liquid crystals which undergo color changes as their temperatures are varied. Contact methods are generally not very sensitive, have relatively long response times, and require an application procedure prior to thermal inspection. Non-contact methods permit remote sensing of the thermal patterns, and are the most popular thermal inspection methods.

\subsection{Infrared Thermography}

\subsubsection{Principle of Method}

An object having a temperature above absolute zero will emit energy in the form of thermal photons. The wavelengths of the radiation fall within certain bands depending on the temperature. For example, at room temperature, the wavelengths are typically from 4 to 40 $\mu \mathrm{m}$ with a peak wavelength of about $10 \mu \mathrm{m}$ [1]. At very high temperatures, the wavelengths of the emitted radiation are reduced to less than 1 micrometer and fall within the visible spectrum. The longer wavelength radiation associated with room temperature is not visible to the eye and is called infrared radiation. By using instruments that can detect infrared radiation, it is possible to "see" differences in surface temperatures. This is the basis of the thermal inspection method known as infrared thermography.

The rate of radiant energy emission per unit area of surface (W) is given by the Stefan Boltzmann Law:

$$
\mathrm{W}=\mathrm{e} \delta \mathrm{T}^{4}
$$

where $T$ is the absolute temperature,

$e$ is the emissivity, and

$\delta$ is the Stefan Boltzmann constant

$\left(5.67 \times 10^{-12} \mathrm{watt} / \mathrm{cm}^{2} /{ }^{\circ} \mathrm{K}^{4}\right)$.

Thus, changes in temperature of a surface produce more than proportional changes in emitted energy, and this enables the detection of temperature differences as low as $0.2{ }^{\circ} \mathrm{C}$ with the available detection equipment. Emissivity refers to the efficiency of energy radiation by the surface. The maximum radiation efficiency occurs in a "black body" and this is given an emissivity value of 1 . All real surfaces have an emissivity while rough textured non-metals have high emissivity. Since detection methods are based on the intensity of emitted radiation, a change in emissivity at various points on the surface may be incorrectly interpreted as a change in temperature. Surfaces with non-uniform or low emissivity can be painted with high emissivity coatings.

\subsubsection{Remote Inspection}

Infrared thermography permits remote inspection of the test object. This is made possible because air is practically transparent to the infrared wavelengths associated with near room-temperature conditions [17]. However, high water content will reduce the transmission of infrared radiation through air so that problems may arise under humid conditions. The most common method for detecting infrared radiation is with semiconductor crystals whose electrical properties are altered by incident infrared radiation. For best sensitivity, the crystals should be kept cold with liquid nitrogen and this places some limitations on the portability of the detection systems. Dewar flasks are required to hold the liquid nitrogen, and the nitrogen needs to be replaced as it evaporates. 
Infrared scanners consist of a sensing or camera-like unit and a display or recording unit. The elements of a camera unit are shown schematically in figure 16 and these components scan the viewed area and focus the individual "points" on a sensor or radiation detector. As shown in figure 16, the radiant flux which is related to the temperature of the selected viewing area passes through an infrared transparent lens and a mechanicaloptical scanner. The mechanical-optical scanner, which consists of rotating or vibrating mirrors or prisms, provides a vertical and horizontal scan of the virtual image from the lens.

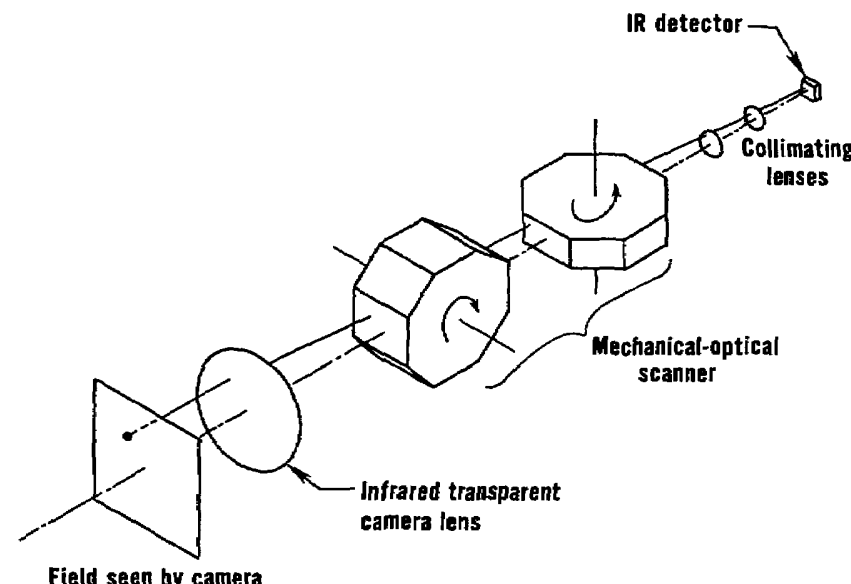

FIGURE 16. Schematic of infrared camera.

The picture is presented as shades of gray corresponding to variations in surface temperatures of the viewed object. A calibration strip is also shown so that the shades can be converted to absolute temperatures if desired. It is also possible to have a color display in which different temperatures are shown with different colors.

\subsection{Applications}

Thermal inspection methods have been applied for detecting disbonds in laminated materials, entrapped moisture, material density gradients, and anomalies in castings [1]. In the construction area, infrared thermography has been applied to compare thermal resistances of roofs, to detect water penetration into built-up roofs, to detect heat loss through walls and roofs of buildings, and to detect overloaded electrical circuits [17]. Recently, infrared thermography has been used to detect deteriorated regions in bridge decks [38].
Thermal inspection equipment is generally portable and a permanent record (photograph) can be made of the inspection results. By using thermal infrared thermography, inspections can be performed without direct access to the surface and large areas can be rapidly inspected.

In determining the size and location of detectable flaws, it should be recognized that under heat flow conditions the surface temperature patterns will be a function of the type and size of the discontinuity, the heat intensity applied or flowing to the surface of the object, and the observation time [1]. The sensitivity of infrared thermography in detecting internal flaws is a complex function of these variables. The results of such inspections, therefore, should be carefully interpreted.

\section{Ultrasonic Pulse Methods}

In the ultrasonic pulse methods sound waves which are beyond the audible range are induced in a test object generally by means of a peizoelectric transducer, and either reflected waves or those passing through the object are detected by a similar type of transducer $[1,4,39-42]$. When reflected waves are detected, the technique is referred to as "pulse-echo" and the transmitting transducer may also act as the receiver. Waves passing through the object (velocity method) are detected with a second transducer, i.e., a receiving transducer.

The application of ultrasonic inspection is based on two principles: (1) the velocity of the acoustic waves in a material is a function of its elastic constants and density; and (2) when an acoustic wave encounters an interface between dissimilar materials, a portion of the wave is reflected. The amount of reflection depends on the mismatch in acoustic impedance (product of wave velocity and density) of the materials with the amount of reflection increasing with the mismatch.

\subsection{Ultrasonic Pulse Velocity Method}

The ultrasonic pulse velocity method is one of the most universally ased NDE methods for assessing the quality of concrete. It has been used in both the laboratory and in the field for the past $\mathbf{4 0}$ years. Some field applications have included checking the quality of concrete in bridge piers, pavements and dams.

\subsubsection{Principle of Method}

The ultrasonic pulse velocity method is based on measuring the travel time of an ultrasonic pulse passing 
through a material. The pulse generated by an electroacoustic transducer is picked up by a receiver transducer and amplified.

The time of travel of the pulse is measured electronically [42]. A commercial instrument for measuring the ultrasonic pulse velocity of concrete is shown in figure 17.

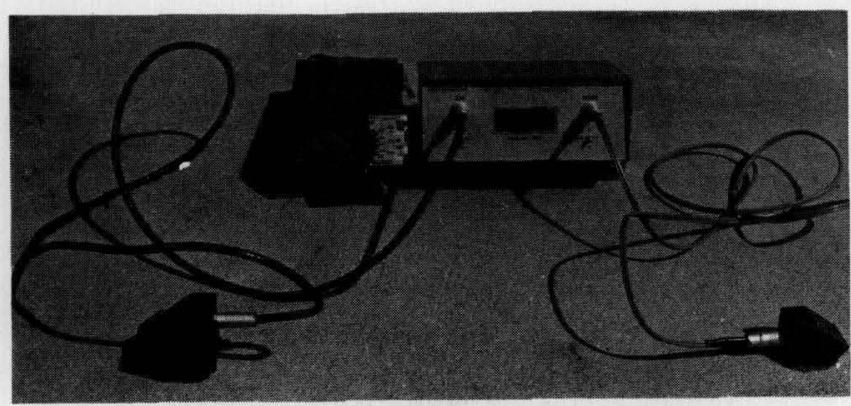

FIGURE 17. Ultrasonic pulse velocity equipment.

When a mechanical pulse is applied to a material by an electroacoustical transducer, waves are induced in the material. Usually longitudinal waves are used in testing concrete. These waves are transmitted by particles vibrating parallel to the direction of propagation. The velocity of the waves is controlled by the elastic properties and density of the material, and is virtually independent of the geometry of the object being tested.

If a longitudinal wave encounters a discontinuity such as a crack or void, it may "bend," i.e., be diffracted around the discontinuity. This increases the internal distance the wave must pass between the transmitting and pickup transducers, and consequently its travel time increases. Therefore, for a given separation of the transducers, and for a given concrete, the travel time of a longitudinal wave will be affected by changes in density and elastic properties along the travel path.

Several ultrasonic pulse velocity units are commercially available for testing concrete and cost about $\$ 4000$. They can be used to test concrete having a thickness up to about $75 \mathrm{ft}(30 \mathrm{~m})$ depending on the specific model.

\subsubsection{Application for Assessment of Condition of Concrete by Ultrasonic Pulse Velocity}

The ultrasonic pulse velocity method is considered to be the best NDE method for determining the uniformity of in situ concrete, and ASTM Standard C 597 gives the standard test procedure to use. For example, velocity measurements have been successfully used to detect deteriorated regions in concrete bridges and the uniformity of concrete in walls [4]. In general, if substantial variations in pulse velocities are found in a structure, without any apparent reason (such as intentional changes in materials, concrete mix, or construction procedures), this indicates that unsound concrete is present.

A general rating which has been proposed [43] to assess the relative quality of concrete is presented in table . Three criteria should be used with caution as differences in the qualities of concrete cannot be as sharply delineated as indicated in table 12 . In addition, velocity is affected by the density and amount of aggregate in the concrete. A crude assessment of the quality of similar types of concrete can be made, however, using these criteria. For example, if one concrete has a pulse velocity of $15,000 \mathrm{ft} / \mathrm{s}(4570 \mathrm{~m} / \mathrm{s})$ while another concrete with a similar composition has a velocity below $10,000 \mathrm{ft} / \mathrm{s}(3050 \mathrm{~m} / \mathrm{s})$, then there is clearly a significant difference in their qualities.

Table 2. Pulse Velocities in Concrete [43]

\begin{tabular}{cll}
\hline & \multicolumn{1}{c}{ Pulse Velocity } & \\
$\mathrm{ft} / \mathrm{s}$ & \multicolumn{1}{c}{$\mathrm{m} / \mathrm{s}$} & General Condition \\
\hline & & \\
Above 15,000 & $(4570)$ & Excellent \\
$12,000-15,000$ & $(3660-4570)$ & Good \\
$10,000-12,000$ & $(3050-4570)$ & Questionable \\
$7,000-10,000$ & $(2130-3050)$ & Poor \\
Below 7,000 & $(2130)$ & Very Poor \\
\hline
\end{tabular}

\subsubsection{Estimation of Strength Properties of Concrete}

Numerous investigations have attempted to correlate compressive and flexural strengths of concrete with pulse velocity. Some correlations have been obtained in laboratory studies, provided that mix proportions, the cement, types of aggregate, and curing conditions were not varied. If these factors were varied, however, no usable correlations were obtained. For example, Parker [44] made a comparison of pulse velocities and compressive strengths for concretes made from only one type of aggregate but containing different cements from different sources and a variety of admixtures. His analysis of the total data indicated that at the 95 percent confidence level the estimate strength of 4440 psi $\mathbf{3 0 . 7}$ $\mathrm{MN} / \mathrm{m}^{2}$ ) concrete ranged from about 2100 to $6000 \mathrm{psi}$ (14.5 to $\left.41.8 \mathrm{MN} / \mathrm{m}^{2}\right)$. Obviously, the ultrasonic pulse method cannot be used to obtain reliable estimates of the compressive strength of concrete in structure when its composition is unknown.

Probably the best concluding remarks regarding strength prediction from wave propagation methods are those stated by Jones [45]: 
"In spite of the promising results of the early investigations, it must be concluded that no general relation has been found between the dynamic modulus of elasticity and its flexural or compressive strength."

This statement still holds if one substitutes "pulse velocity" for "dynamic modulus of elasticity."

\subsubsection{Extraneous Effects on Velocity Measurements}

The measurement of the pulse velocity of concrete is affected by several factors which are not intrinsic properties of concrete, and, therefore, are not a function of the quality or strength of concrete [4]:

(1) Smoothness of concrete at transducer contact area. Good acoustical contact between the transducers and concrete is required. In addition, a coupling agent such as an oil or a jelly must be used.

(2) Concrete temperatures outside of the range between $41^{\circ}$ and $86^{\circ} \mathrm{F}\left(5^{\circ}\right.$ and $30^{\circ} \mathrm{C}$ ) affect the measured pulse velocity. Below this temperature range, the velocity is increased, and above the velocity is decreased.

(3) Moisture condition of concrete. Pulse velocity generally increases as the moisture content of concrete increases, while compressive strength decreases as moisture content increases.

(4) Presence of reinforcing steel. The pulse velocity in steel is 1.2 to 1.9 times the velocity in concrete. Measurements made near steel reinforcing bars, therefore, may not be representative of the concrete. If possible, measurements should be made perpendicular to the longitudinal axis of the bars. If measurements must be made parallel to the longitudinal axis of the steel bars, crude correction factors are available.

\subsection{Ultrasonic Pulse Echo Method}

\subsubsection{Principle of Method}

In the ultrasonic pulse echo method waves which are reflected off of discontinuities (e.g. cracks and voids) and from interfaces (e.g. interfaces between concrete and steel or between concrete and air) are recorded. Both the transmitting and receiving transducers are contained in the same probe, thus, only those waves which are reflected back at nearly $180^{\circ}$ to the incident waves are detected. The penetrating ability of the ultrasonic pulse and the minimum size of detectable flaws are influenced by the frequency of the generated waves. High frequency results in less penetration but better sensitivity than low frequency.

\subsubsection{Applications}

Echo techniques have been extensively used to identify and locate discontinuities and defects in metals and welds [1, 39-41]. The echo technique is one of the most versatile and accepted NDE methods for metals. However, its application to concrete has been slow, largely because the extensive pore system, presence of cracking, and the heterogeneous nature of concrete result in multiple reflections when high frequency pulses are used which both significantly attenuate the reflected waves and complicate the interpretation of the observations. It may, however, be possible to combine the echo method with acoustic impact (see section 2) so that low frequency waves are generated which would be insensitive to microscopic flaws but could be used to detect large discontinuities. Commercial equipment is not at present available for this type of testing.

\subsubsection{Advantages and Limitations}

Ultrasonic pulse-echo inspection offers several advantages over other NDE methods capable of detecting internal flaws in a test object such as gamma radiography [1]. For example, acoustic waves have excellent penetrating ability, and with proper instrument selection thick sections on the order of $10 \mathrm{~m}$ or more can be inspected. Very small flaws may be detected and their location and geometry may be estimated with reasonable accuracy. In addition, test results are immediately available, the equipment is lightweight and portable, and acoustic waves pose no known health hazard.

Because of the indirect nature of flaw detection by ultrasonic pulse-echo inspection, a high level of expertise is required to plan an inspection program. A thorough understanding of the nature of the interactions between the acoustic waves and different discontinuities is required in order to properly interpret test results. The physical testing, on the other hand, may be performed by technical level personnel after proper training. Before ultrasonic inspection equipment can be used, calibration and referencing with standards must be performed, otherwise test results are difficult to interpret. The nature of the calibrations will depend on the particular inspection program. 


\section{Visual Inspection}

Often surface defects can be detected visually using methods to enhance ordinary visual acuity. Optical magnification or other techniques which can be used to increase the apparent size of surface cracks are covered in this section.

\subsection{Optical Magnification}

Available magnifying instruments range from simple inexpensive glasses to expensive microscopes. Some fundamental principles about the operating characteristics of magnification instruments need to be understood before selecting a system for a particular application. First, the focal length decreases as the magnification power increases. This means that when high magnification is desired, the primary lens must be placed close to the test object. The field of view (that portion of the object that can be seen at any instant) also decreases as magnification power increases. A small field of view means that it will be tedious to examine a large surface area. Another important parameter is the depth of field, which refers to the elevation difference of rough textured surfaces that can be viewed in focus simultaneously; the depth of field decreases as the magnification power of the instrument increases. Therefore, to inspect a roughtextured surface, a magnification power should be selected that gives a sufficiently large depth of field so that the "hills" and "valleys" will be simultaneously in focus. Finally, the illumination intensity required to clearly see surface flaws will increase as the magnification power increases. High magnification may require using a supplementary light source to augment the available lighting.

A useful tool for field inspection is a pocket magnifier with a built-in measuring scale which enables measurement of flaw dimensions. A stereomicroscope is very useful when a three-dimensional view of the surface is required. With this instrument one can determine whether a crack is shallow or extends for considerable distance into the object. By calibrating the focus adjustment, a stereomicroscope can also be used as a depth gage to measure the approximate height of surface irregularities.

\subsection{Fiberscope}

Another useful instrument is the fiberscope, which is composed of a bundle of flexible optical fibes and lens systems. The fiberscope can be used to look inside a cavity by inserting it through a small access hole. Some of the fibers in the bundle are used to carry light into the cavity and illuminate the field of view. The viewing head can be rotated so that a wide viewing angle is possible from a single access hole. A fiberscope, because of the discrete nature of light transmission by the fibers may not have as good a resolution ability as a boroscope, which is a straight rigid tube using a lens system for viewing. The best resolution is obtained by an instrument with small diameter fibers in which the fiber density per unit area is high. To use a fiberscope requires drilling access holes if natural channels are not present, and the holes must intercept cavities. The acoustic impact technique (section 4.2) can be used to locate hollow spots for subsequent fiberscope inspection.

\subsection{Liquid Penetrant Inspection}

In this method a highly visible dye is used to coat the surface to be inspected $[1,46]$. Any cracks that are open to the surface will soak up the dye because of surface tension and capillary effects. After application of the dye the surface is cleaned. The dye which penetrated into cracks remains and can be visually observed, thereby disclosing the presence of cracks. The method is one of the most inexpensive inspection methods available. It only enables detection, however, of open flaws that intersect the surface of the object.

\subsubsection{Description of Method}

Dye penetration inspection involves the following steps: (1) cleaning the surface; (2) applying the dye; (3) removing excess dye from surface; (4) applying a developer; and (5) interpreting the results.

The objective of the cleaning procedure is to remove foreign matter from within cracks so that dye can penetrate into them. The specific procedures to be used will depend on the condition of the surface. Care must be taken to ensure that the cleaning process does not smear the cracks or fill the cracks with residues. For example, sandblasting a soft metal may "hammer" the surface to such an extent that cracks become closed and undetectable.

The dye may be applied to the surface by spraying, painting or dipping. Two types of dye are available: one is for viewing under ordinary light and is usually a brilliant red color; the other is fluorescent and viewed under ultraviolet light. Fluorescent dyes offer the best sensitivity for detecting small cracks. The dye is allowed to remain on the surface from $\mathbf{1 0}$ to $\mathbf{3 0} \mathrm{min}$ (dwell time) before cleaning the surface.

Cleaning can be done by flushing the surface with water or by wiping with a rag dampened with solvent. For water cleaning, the dye requires an emulsifying agent so that it can be completely removed with water. 
The agent is either already included within the dye or it is added to the coated surface prior to washing. This phase is very important; all excess dye needs to be removed otherwise there will be false indications of cracks. If the surface is very porous, inspection by this method may be difficult; if dye is not removed from the pores, there will be a loss of contrast as the surface will take on a color that is a light shade of the dye. If dye is removed from all pores, it will probably also be removed from some of the cracks.

After cleaning, the surface is allowed to dry and a developer is added. Developer is a fine powder added for two reasons: (1) it provides a uniform colored background which increases contrast; and (2) it has a blotting effect, thereby drawing up the dye from within the cracks. The blotting action increases the apparent width of the cracks so that they become more visible. Developer can be applied as a dry powder or as a paint. The thickness of the developer layer is important, if it is too thin there may not be good contrast; and if it is too thick, it may mask the cracks.

Finally, the prepared surface is inspected. If the application procedure was correctly performed, the presence of cracks will be clearly shown. However, the inspector needs to be familiar with the patterns associated with "irrelevant indications," i.e., patterns not due to cracks but due to other sources such as improper cleaning.

\subsubsection{Advantages and Limitations}

Although dye penetrant inspection relies on simple principles, a certain amount of skill is necessary to properly carry out the process. The operator needs to know which materials to use for a particular application and to understand how the materials respond to different temperature conditions. Portable kits are available in which the various chemicals are contained in aerosol cans, thus making field inspection possible. At present, the technology has been developed primarily for inspection of metals, and the applicability of the procedures to masonry or concrete structures with surfaces of high porosity has not been demonstrated.

\section{COMBINATIONS OF NONDESTRUCTIVE EVALUATION METHODS}

While no single NDE method may be entirely satisfactory for predicting the strength or quality of a material, combinations of methods which respond to different factors may give more definite information. The combined NDE approach has been largely developed for evaluating concrete and, therefore, only applications to concrete will be described.

To predict the compressive strength of in situ concrete more accurately, the results of two or even three different NDE methods have been combined. The most popular combination has been the ultrasonic pulse velocity method in conjunction with the rebound hammer [47]. Other common combinations are the ultrasonic pulse velocity method and the measurement of the damping constant of concrete [48], and the ultrasonic pulse velocity and pulse attenuation methods [49]. The latter two combinations are essentially laboratory research techniques and therefore will not be discussed further.

The results of two methods can be combined in a linear equation of the form:

$$
f_{\mathrm{c}}^{\prime}=A\left(\mathrm{NDE}_{1}\right)+B\left(\mathrm{NDE}_{2}\right)+C
$$

where $f_{c}^{\prime}$ is the estimated compressive strength from the combined method, $\mathrm{NDE}_{1}$ and $\mathrm{NDE}_{2}$ are the results of the individual methods, and $A, B$, and $C$ are empirically determined constants.

\section{Combination of Ultrasonic Pulse Velocity and Rebound Hammer Methods}

This combination of nondestructive tests has been used in Europe, primarily, with the most exhaustive studies being carried out by Facaoaru [50-53]. In this combined approach, measurements of ultrasonic pulse velocity and rebound number are made in situ on concrete. The pulse velocity and rebound number are substituted into a previously derived regression equation to predict compressive strength. It is believed that the multiple regression equation should give a more accurate estimate of compressive strength than either of the individual measurements alone.

Facaoaru [50] has developed calibration charts for standard concrete mixes from which the compressive strengths can be estimated when the pulse velocities and rebound numbers are known. Correction factors have also been developed to be used in the case of nonstandard concrete mixes. This combined method has been used often in Romania to estimate the compressive strength of in situ concrete [50, 52]. Based on his experiences, Facaorau contends that by using the combined method, the following accuracy in predictions of compressive strengths can be obtained:

(1) When composition is known and test specimens or cores are available for calibration purposes, accuracy is within 10 to 15 percent. 
(2) When only the composition of the concrete is known, accuracy is within 15 to 20 percent.

(3) When neither the composition is known nor test specimens or cores are available, accuracy is within 20 to 30 percent.

This suggests that, for case (3), the combined method gives no better prediction of the compressive strength than can be obtained by measuring only the ultrasonic pulse velocity or only the rebound number; in case (2), the improvement is marginal. Therefore, only when the concrete is well characterized is this combined method better than the individual nondestructive methods.

\section{SUMMARY}

Nondestructive evaluation methods (NDE) offer significant advantages over traditional methods for determining the properties of building materials. One of these is the ability to make in-situ measurements of the materials, which virtually eliminates the specimen preparation costs used with ordinary strength testing methods. In-situ measurements are especially valuable in concrete technology because the characteristics of hardened concrete are affected by such factors as thermal history, presence of moisture and degree of compaction. Testing concrete in the structure ensures that these factors have been included. Another advantage of NDE methods is that they enable re-testing of the material or component at later ages so that material degradation with time can be determined. Finally, a majority of the NDE methods are economical and simple tests, permitting a larger number of tests for the same effort, compared with traditional test methods.

A key feature in the successful application of NDE methods is an understanding of their operating principles and their inherent limitations. These aspects have been emphasized in the paper are summarized in table 3 . The numbers shown for each method refer to the section numbers in the text. The principle of operation will often dictate the types of materials and the nature of the characteristics that can be probed with each method.

In selecting which particular NDE method one should use, consideration should be given to the following factors: (1) the type of material, since many methods are applicable to only a particular type, such as concrete or steel; (2) the properties being sought; (3) the level of expertise required not only to perform but also to interpret the tests; and (4) the desired level of accuracy.

The required calibration procedure should also be considered as this may increase the total effort to perform an acceptable nondestructive inspection program.

The reliability of each method for a particular application depends on the relationship between the quantity measured directly by the method and the desired property. Methods are less reliable if their measurements are strongly affected by factors which have negligible effect on the desired properties. Reliability can often be improved by careful calibration of the method; this is especially critical to some of the NDE methods for concrete strength prediction.

The future offers many opportunities for the growth of NDE methods in building technology. The demand for such techniques is increasing, as is the level of research to refine existing methods and develop new ones. It is anticipated that the exploitation of microcomputers will lead to a new generation of methods capable of measuring characteristics that are presently beyond our reach.

Preparation of this report was sponsored by the U.S. Army Construction Engineering Laboratory, Champaign, IL 61820. The authors appreciate the valuable suggestions and information provided by Dr. Paul Howdyshell of the Engineering Laboratory and by Mr. Harry Berger, Office of Nondestructive Evaluation, National Bureau of Standards. 
TABLE 3. Survey of Commonly used NDE Methods for Inspection Building Materials

\begin{tabular}{|c|c|c|c|c|c|c|}
\hline Method & Principle & $\begin{array}{c}\text { Main } \\
\text { Applications }\end{array}$ & $\begin{array}{c}\text { Equipment } \\
\text { Cost }\end{array}$ & $\begin{array}{c}\text { User } \\
\text { Expertise }\end{array}$ & Advantages & Limitations \\
\hline $\begin{array}{l}\text { 1. Acoustic Emis- } \\
\text { sion }\end{array}$ & $\begin{array}{l}\text { During crack } \\
\text { growth or plastic } \\
\text { deformation, the } \\
\text { rapid release of } \\
\text { strain energy pro- } \\
\text { duces acoustic } \\
\text { (sound) waves that } \\
\text { can be detected by }\end{array}$ & $\begin{array}{l}\text { Continuous } \\
\text { monitoring of } \\
\text { structure during } \\
\text { service life to } \\
\text { detect impending } \\
\text { failure; monitor- } \\
\text { ing performance } \\
\text { of structure dur- }\end{array}$ & $\begin{array}{l}\$ 10,000 \text { for single } \\
\text { pickup, up to } \\
\$ 100,000 \text { for } \\
\text { multichannel } \\
\text { pickup. }\end{array}$ & $\begin{array}{l}\text { Extensive } \\
\text { knowledge re- } \\
\text { quired to plan test } \\
\text { and to interpret } \\
\text { results. }\end{array}$ & $\begin{array}{l}\text { Monitors struc- } \\
\text { tural response to } \\
\text { applied load; } \\
\text { capable of de- } \\
\text { tecting onset of } \\
\text { failure; capable of } \\
\text { locating source of } \\
\text { possible failure. }\end{array}$ & $\begin{array}{l}\text { Requires means of } \\
\text { loading structure; } \\
\text { complex electronic } \\
\text { equipment is re- } \\
\text { quired. }\end{array}$ \\
\hline
\end{tabular}

sensors attached

test object.

\begin{tabular}{ll}
\hline 2. Acoustic Im- & Surface of object \\
pact (Hammer & is struck with \\
Test) & hammer (usually \\
& metallic). The fre- \\
& quency, through \\
& transmission time, \\
& and damping \\
& characteristics of \\
& the "ringing" can \\
& give an indication \\
& of the presence of \\
& defects.
\end{tabular}

2. Acoustic Impact (Hammer defects.

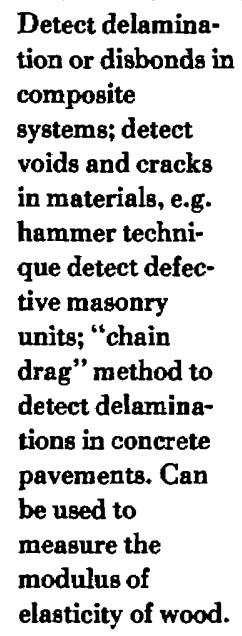

Geometry and mass of test object influences results; poor discrimination; reference standards required for electronic testing.

\begin{tabular}{|c|c|c|c|c|c|c|}
\hline $\begin{array}{l}\text { 3. Cast-in-Place } \\
\text { Pullout }\end{array}$ & $\begin{array}{l}\text { Measure the force } \\
\text { required to pull } \\
\text { ont the steel rod } \\
\text { with enlarged } \\
\text { head cast in con- } \\
\text { crete. Pullout } \\
\text { forces produce } \\
\text { tensile and shear }\end{array}$ & $\begin{array}{l}\text { Estimation of } \\
\text { compressive and } \\
\text { tensile strengths of } \\
\text { concrete. }\end{array}$ & $\$ 1000$ to $\$ 6000$ & $\begin{array}{l}\text { Low, can be used } \\
\text { by field concrete } \\
\text { testers and inspec- } \\
\text { tors. }\end{array}$ & $\begin{array}{l}\text { Only NDE } \\
\text { method which } \\
\text { directly measures } \\
\text { inplace strength of } \\
\text { concrete; appears } \\
\text { to give good } \\
\text { prediction of con- } \\
\text { crete strength. }\end{array}$ & $\begin{array}{l}\text { Pullout devices } \\
\text { must be inserted } \\
\text { during construc- } \\
\text { tion. Cone of con- } \\
\text { crete may be pull- } \\
\text { ed out, } \\
\text { necessitating } \\
\text { minor repairs. }\end{array}$ \\
\hline
\end{tabular}

\begin{tabular}{|c|c|c|c|c|c|c|}
\hline $\begin{array}{l}\text { 4. Electrical } \\
\text { Potential } \\
\text { Measurements }\end{array}$ & $\begin{array}{l}\text { Electrical poten- } \\
\text { tial of Bteel rein- } \\
\text { forcement } \\
\text { measured. Poten- } \\
\text { tial indicates pro- } \\
\text { bability of corro- } \\
\text { sion. }\end{array}$ & $\begin{array}{l}\text { Determining con- } \\
\text { dition of steel } \\
\text { rebars in concrete }\end{array}$ & $\$ 1000$ to $\$ 2000$ & $\begin{array}{l}\text { Moderate. User } \\
\text { must be able to } \\
\text { recognize pro- } \\
\text { blems. }\end{array}$ & $\begin{array}{l}\text { Portable equip- } \\
\text { ment; field } \\
\text { measurements } \\
\text { readily made; ap- } \\
\text { pears to give } \\
\text { reliable informa- } \\
\text { tion. }\end{array}$ & $\begin{array}{l}\text { Does not provide } \\
\text { information on } \\
\text { rate of corrosion. } \\
\text { Requires access to } \\
\text { reinforcing bars. }\end{array}$ \\
\hline 5.1 Eddy Current & $\begin{array}{l}\text { An electrically ex- } \\
\text { cited coil induces } \\
\text { eddy current flow } \\
\text { and an associated } \\
\text { electromagnetic } \\
\text { field in metal. } \\
\text { Flaws alter in- } \\
\text { duced electro- } \\
\text { magnetic field } \\
\text { which in turn }\end{array}$ & $\begin{array}{l}\text { Inspection of } \\
\text { metal parts for } \\
\text { cracks, inclusions, } \\
\text { seams and laps; } \\
\text { measurement of } \\
\text { thickness of non- } \\
\text { metalic coating on } \\
\text { metals; detection } \\
\text { of improper alloy } \\
\text { composition. }\end{array}$ & Minimum $\$ 3000$ & Moderate. & $\begin{array}{l}\text { Extremely sen- } \\
\text { sitive to change in } \\
\text { properties and } \\
\text { characteristics of } \\
\text { metal; portable. }\end{array}$ & $\begin{array}{l}\text { Requires calibra- } \\
\text { with standards; } \\
\text { limited depth of } \\
\text { penetration; only } \\
\text { applicable to } \\
\text { metals; sensitive } \\
\text { to geometry of } \\
\text { part. }\end{array}$ \\
\hline
\end{tabular}




\begin{tabular}{|c|c|c|c|c|c|c|}
\hline & $\begin{array}{l}\text { alters the im- } \\
\text { pedance of the ex- } \\
\text { citation coil. } \\
\text { Change in coil im- } \\
\text { pedance indicates } \\
\text { presence of flaw or } \\
\text { anomaly. }\end{array}$ & & & & & \\
\hline Method & Principle & $\begin{array}{c}\text { Main } \\
\text { Applications }\end{array}$ & $\begin{array}{c}\text { Equipment } \\
\text { Cost }\end{array}$ & $\begin{array}{c}\text { User } \\
\text { Expertise }\end{array}$ & Advantages & Limitations \\
\hline $\begin{array}{l}5.2 \text { Magnetic } \\
\text { Field Testing }\end{array}$ & $\begin{array}{l}\text { An electrically } \\
\text { energized primary } \\
\text { coil is brought } \\
\text { near test object, a } \\
\text { voltage is induced } \\
\text { in a secondary coil } \\
\text { and its magnitude } \\
\text { is compared to a } \\
\text { reference stan- } \\
\text { dard. Magnetic } \\
\text { proper- } \\
\text { ties of test object } \\
\text { affect induced } \\
\text { voltages. }\end{array}$ & $\begin{array}{l}\text { Distinguishing } \\
\text { between steels } \\
\text { based on dif- } \\
\text { ferences in com- } \\
\text { position, hard- } \\
\text { ness, heat treat- } \\
\text { ment, or residual } \\
\text { stresses; locating } \\
\text { hidden magnetic } \\
\text { parts; measuring } \\
\text { thickness of non- } \\
\text { magnetic coatings } \\
\text { or films. }\end{array}$ & $\$ 3000$ & $\begin{array}{l}\text { Low to moderate } \\
\text { depending on ap- } \\
\text { plication. }\end{array}$ & $\begin{array}{l}\text { Portable; rapid } \\
\text { test; easily detects } \\
\text { magnetic objects } \\
\text { even if embedded } \\
\text { in nonmagnetic } \\
\text { material. }\end{array}$ & $\begin{array}{l}\text { Applicable only to } \\
\text { ferromagnetic } \\
\text { alloys; reference } \\
\text { standards and } \\
\text { calibration may be } \\
\text { required for some } \\
\text { applications. }\end{array}$ \\
\hline 5.3 Covermeter & $\begin{array}{l}\text { Presence of steel } \\
\text { affects the } \\
\text { magnetic field of a } \\
\text { probe. Closer pro- } \\
\text { be is to steel, the } \\
\text { greater the effect. } \\
\text { Principle of opera- } \\
\text { tion is similar to } \\
\text { eddy current } \\
\text { method. }\end{array}$ & $\begin{array}{l}\text { Determination of } \\
\text { presence, location } \\
\text { and depth of } \\
\text { rebars in concrete } \\
\text { and masonry } \\
\text { units. }\end{array}$ & $\$ 800$ to $\$ 1500$ & $\begin{array}{l}\text { Moderate. Easy to } \\
\text { operate. Training } \\
\text { needed to inter- } \\
\text { pret results. }\end{array}$ & $\begin{array}{l}\text { Portable equip- } \\
\text { ment, good results } \\
\text { if concrete is light- } \\
\text { ly reinforced. }\end{array}$ & $\begin{array}{l}\text { Difficult to inter- } \\
\text { pret results if con- } \\
\text { crete is heavily } \\
\text { reinforced or if } \\
\text { wire mesh is pre- } \\
\text { sent. }\end{array}$ \\
\hline $\begin{array}{l}5.4 \text { Magnetic } \\
\text { Particle Inspec- } \\
\text { tion }\end{array}$ & $\begin{array}{l}\text { Presence of } \\
\text { discontinuities in } \\
\text { ferromagnetic } \\
\text { material will cause } \\
\text { leakage field to be } \\
\text { formed at or } \\
\text { above the discon- } \\
\text { tinuity when the } \\
\text { material is } \\
\text { magnetized. The } \\
\text { presence of the } \\
\text { discontinuity is } \\
\text { detected by use of } \\
\text { ferromagnetic } \\
\text { magnetic particles } \\
\text { applied over the } \\
\text { surface which } \\
\text { form an outline of } \\
\text { the discontinuity. }\end{array}$ & $\begin{array}{l}\text { Usually used to } \\
\text { detect fatigue } \\
\text { cracks inservice } \\
\text { metal components } \\
\text { and inspection } \\
\text { during production } \\
\text { control. Ap- } \\
\text { plicable to inspec- } \\
\text { ting welds. }\end{array}$ & Minimum $\$ 2000$ & $\begin{array}{l}\text { Expertise required } \\
\text { to plan non- } \\
\text { routine tests. } \\
\text { Moderate exper- } \\
\text { tise to perform } \\
\text { test. }\end{array}$ & $\begin{array}{l}\text { Capable of detec- } \\
\text { ting subsurface } \\
\text { cracks if they are } \\
\text { larger than sur- } \\
\text { face cracks; size } \\
\text { and shape of com- } \\
\text { ponent poses no } \\
\text { limitation; por- } \\
\text { table equipment } \\
\text { available. }\end{array}$ & $\begin{array}{l}\text { Non-ferro- } \\
\text { magnetic metal } \\
\text { cannot be in- } \\
\text { spected; coatings } \\
\text { affect sensitivity; } \\
\text { demagnetization } \\
\text { may be required } \\
\text { after testing. }\end{array}$ \\
\hline 6. Leak Testing & $\begin{array}{l}\text { Telltale } \\
\text { substances added } \\
\text { to piping system } \\
\text { under pressure } \\
\text { reveal presence of }\end{array}$ & $\begin{array}{l}\text { Detection of leaks } \\
\text { in pipes carrying } \\
\text { fluids. }\end{array}$ & $\begin{array}{l}\text { Wide range } \\
\text { depending on } \\
\text { detection method. } \\
\$ 100 \text { to } \$ 5000 \text {. }\end{array}$ & $\begin{array}{l}\text { Low to high } \\
\text { depending on ap- } \\
\text { plication. }\end{array}$ & $\begin{array}{l}\text { Can locate leaks } \\
\text { too small to be } \\
\text { found by any } \\
\text { other NDE } \\
\text { method. }\end{array}$ & $\begin{array}{l}\text { Difficult to deter- } \\
\text { mine position of } \\
\text { leaks in pipes hid- } \\
\text { den in wall or } \\
\text { floor cavities. }\end{array}$ \\
\hline
\end{tabular}


Table 3 (Cont.)

\begin{tabular}{|c|c|c|c|c|c|c|}
\hline Method & Principle & $\begin{array}{c}\text { Main } \\
\text { Applications }\end{array}$ & $\begin{array}{c}\text { Equipment } \\
\text { Cost }\end{array}$ & $\begin{array}{c}\text { User } \\
\text { Expertise }\end{array}$ & Advantages & Limitations \\
\hline & $\begin{array}{l}\text { leaks. Sound } \\
\text { amplification to } \\
\text { detect leak. }\end{array}$ & & & & & \\
\hline $\begin{array}{l}\text { 8.1 Moisture } \\
\text { Meter-Electrical } \\
\text { Resistance Probe }\end{array}$ & $\begin{array}{l}\text { Electrical } \\
\text { resistance between } \\
\text { two probes in- } \\
\text { serted into test } \\
\text { component is } \\
\text { measured. The } \\
\text { resistance } \\
\text { decreases with in- } \\
\text { creased moisture } \\
\text { contents. }\end{array}$ & $\begin{array}{l}\text { Measurement of } \\
\text { moisture contents } \\
\text { of timber, roofing } \\
\text { materials and } \\
\text { soils. }\end{array}$ & $\$ 300$ to $\$ 1000$ & Low & $\begin{array}{l}\text { Equipment is in- } \\
\text { expensive, simple } \\
\text { to operate and } \\
\text { many measure- } \\
\text { ments can be } \\
\text { rapidly made. }\end{array}$ & $\begin{array}{l}\text { Not reliable at } \\
\text { high moisture con- } \\
\text { tents; needs to be } \\
\text { calibrated; precise } \\
\text { results are not } \\
\text { usually obtained. }\end{array}$ \\
\hline $\begin{array}{l}\text { 8.2 Moisture } \\
\text { Meter- } \\
\text { Capacitance }\end{array}$ & $\begin{array}{l}\text { Water affects die- } \\
\text { electric constant } \\
\text { and the dielectric } \\
\text { loss factor of } \\
\text { materials. } \\
\text { Measurement of } \\
\text { either property } \\
\text { can be used to } \\
\text { estimate moisture } \\
\text { contents. }\end{array}$ & $\begin{array}{l}\text { Measurement of } \\
\text { moisture contents } \\
\text { of timber and } \\
\text { roofing materials. }\end{array}$ & $\$ 2,000$ to $\$ 5,000$ & $\begin{array}{l}\text { Low level of ex- } \\
\text { pertise required to } \\
\text { use but experience } \\
\text { needed to plan } \\
\text { test. }\end{array}$ & $\begin{array}{l}\text { Portable; simple } \\
\text { to operate; effec- } \\
\text { tive over a wide } \\
\text { range of moisture } \\
\text { contents. }\end{array}$ & $\begin{array}{l}\text { Measurement is } \\
\text { only of surface } \\
\text { layer; calibration } \\
\text { required; results } \\
\text { affected by roof- } \\
\text { ing aggregates; } \\
\text { other factors af- } \\
\text { fect accuracy. }\end{array}$ \\
\hline $\begin{array}{l}\text { 8.3 Moisture } \\
\text { Meter-Neutron }\end{array}$ & $\begin{array}{l}\text { Fast neutrons are } \\
\text { slowed by interac- } \\
\text { tions } v \text { ith hydro- } \\
\text { gen atoms. } \\
\text { Backscattered } \\
\text { slowed neutrons } \\
\text { are measured, the } \\
\text { number of which } \\
\text { are proportional } \\
\text { to the amount of } \\
\text { hydrogen } \\
\text { atoms present in a } \\
\text { materiai. }\end{array}$ & $\begin{array}{l}\text { Moisture content } \\
\text { measurements of } \\
\text { soil and roofing } \\
\text { materials. }\end{array}$ & $\$ 4000$ to $\$ 6000$ & $\begin{array}{l}\text { Must be operated } \\
\text { by trained and } \\
\text { licensed person- } \\
\text { nel. }\end{array}$ & $\begin{array}{l}\text { Portable; moisture } \\
\text { measurements can } \\
\text { rapidly be made } \\
\text { on in-service ma- } \\
\text { terials. }\end{array}$ & $\begin{array}{l}\text { Only measures } \\
\text { moisture content } \\
\text { of surface layer } \\
(50 \mathrm{~mm}) \text {; danger- } \\
\text { ous radiation; } \\
\text { hydrogen atoms of } \\
\text { building materials } \\
\text { are measured in } \\
\text { addition to those } \\
\text { of water. }\end{array}$ \\
\hline $\begin{array}{l}\text { 8.3 Nuclear Den- } \\
\text { sity Meter }\end{array}$ & $\begin{array}{l}\text { Gamisa rays are } \\
\text { used to measure } \\
\text { mass density. The } \\
\text { energy loss of the } \\
\text { emitted gamma } \\
\text { rays is propor- } \\
\text { tional to the mass } \\
\text { density of the } \\
\text { material through } \\
\text { which the rays } \\
\text { pass. }\end{array}$ & $\begin{array}{l}\text { Measurement of } \\
\text { density of soils. }\end{array}$ & $\$ 4000$ to $\$ 6000$ & $\begin{array}{l}\text { Must be operated } \\
\text { by trained and } \\
\text { licensed person- } \\
\text { nel. }\end{array}$ & $\begin{array}{l}\text { Portable; density } \\
\text { measurements can } \\
\text { be made without } \\
\text { disturbing the soil. }\end{array}$ & $\begin{array}{l}\text { Calibration neces- } \\
\text { sary; dangerous } \\
\text { radiation; only } \\
\text { measures density } \\
\text { of surface layers. }\end{array}$ \\
\hline
\end{tabular}

\begin{tabular}{lllll}
\hline 9. Tooke Gage & $\begin{array}{l}\text { A V-groove is cut } \\
\text { into the coating } \\
\text { and an illumi- } \\
\text { nated magnifier } \\
\text { equipped with a }\end{array}$ & $\begin{array}{l}\text { Measurement of } \\
\text { the number and } \\
\text { thickness of paint } \\
\text { layers. }\end{array}$ & $\begin{array}{l}\$ 1300 \\
\text { Low }\end{array}$ & $\begin{array}{l}\text { Simple to operate, } \\
\text { portable; measure- } \\
\text { ment can be made } \\
\text { made in coating } \\
\text { and the substrate } \\
\text { is exposed. }\end{array}$ \\
with any type of \\
substrate.
\end{tabular}


Table 3 (Cont.)

\begin{tabular}{|c|c|c|c|c|c|c|}
\hline Method & Principle & $\begin{array}{c}\text { Main } \\
\text { Applications }\end{array}$ & $\begin{array}{l}\text { Equipment } \\
\text { Cost }\end{array}$ & $\begin{array}{c}\text { User } \\
\text { Expertise }\end{array}$ & Advantages & Limitations \\
\hline & $\begin{array}{l}\text { measure the } \\
\text { number and } \\
\text { thickness of the } \\
\text { films. }\end{array}$ & & & & & \\
\hline $\begin{array}{l}\text { 10. Pin Hole } \\
\text { (Holiday) Meter }\end{array}$ & $\begin{array}{l}\text { An earth load is } \\
\text { connected to a } \\
\text { conductive sub- } \\
\text { strate and a probe } \\
\text { (a moistened } \\
\text { sponge) is passed } \\
\text { directly over a } \\
\text { coating. An alarm } \\
\text { is sounded when } \\
\text { the circuit is com- } \\
\text { pleted resulting } \\
\text { from the probe } \\
\text { contacting a pin } \\
\text { hole (holiday). }\end{array}$ & $\begin{array}{l}\text { Determining the } \\
\text { presence of pin } \\
\text { holes in non- } \\
\text { conductive } \\
\text { coatings over } \\
\text { metals. }\end{array}$ & $\$ 200$ to $\$ 1000$ & Low & $\begin{array}{l}\text { Simple to operate; } \\
\text { portable. }\end{array}$ & $\begin{array}{l}\text { Results are } \\
\text { qualitative, e.g., } \\
\text { there is no } \\
\text { measure of the pin } \\
\text { hole size. }\end{array}$ \\
\hline $\begin{array}{l}\text { 11. Proof } \\
\text { Loading }\end{array}$ & $\begin{array}{l}\text { Structure or } \\
\text { system is sub- } \\
\text { jected to loads and } \\
\text { respond is } \\
\text { measured. }\end{array}$ & $\begin{array}{l}\text { Determining safe } \\
\text { capacity and in- } \\
\text { tegrity of struc- } \\
\text { tures. Leak testing } \\
\text { of pressure vessels } \\
\text { and plumbing. }\end{array}$ & $\begin{array}{l}\text { Wide, depending } \\
\text { on application; } \\
\text { often high. }\end{array}$ & $\begin{array}{l}\text { Depends on } \\
\text { nature of tests; } \\
\text { can be high. }\end{array}$ & $\begin{array}{l}\text { Entire structure } \\
\text { can be tested in its } \\
\text { "as-built" condi- } \\
\text { tion. }\end{array}$ & $\begin{array}{l}\text { Can be very cost- } \\
\text { ly; instrumenta* } \\
\text { tion required to } \\
\text { measure response; } \\
\text { careful planning } \\
\text { required; can } \\
\text { damage structure. }\end{array}$ \\
\hline $\begin{array}{l}\text { 12. Windsor } \\
\text { Probe }\end{array}$ & $\begin{array}{l}\text { Probe fired into } \\
\text { concrete and } \\
\text { depth of penetra- } \\
\text { tion is measured. } \\
\text { Surface and sub- } \\
\text { surface hardness } \\
\text { measured. }\end{array}$ & $\begin{array}{l}\text { Estimations of } \\
\text { compressive } \\
\text { strength, unifor- } \\
\text { mity and quality } \\
\text { of concrete. }\end{array}$ & $\begin{array}{l}\$ 1000 \text { plus cost of } \\
\text { probes. }\end{array}$ & $\begin{array}{l}\text { Low, can be } \\
\text { operated by field } \\
\text { personnel. }\end{array}$ & $\begin{array}{l}\text { Equipment is gim- } \\
\text { ple and durable; } \\
\text { good for determin- } \\
\text { ing quality of con- } \\
\text { crete. }\end{array}$ & $\begin{array}{l}\text { Slightly damages } \\
\text { small area; does } \\
\text { not give precise } \\
\text { prediction of } \\
\text { strength. }\end{array}$ \\
\hline $\begin{array}{l}13.1 \text { X-ray } \\
\text { Radiography }\end{array}$ & $\begin{array}{l}\text { Similar to gamma } \\
\text { radiography, ex- } \\
\text { cept X-rays are } \\
\text { used. }\end{array}$ & $\begin{array}{l}\text { To identify hidden } \\
\text { construction } \\
\text { features in } \\
\text { wooden struc- } \\
\text { tures. }\end{array}$ & $\begin{array}{l}\text { Field Equipment } \\
\text { in excess of } \$ 5000\end{array}$ & $\begin{array}{l}\text { Should be } \\
\text { operated by train- } \\
\text { ed personnel } \\
\text { because of radia- } \\
\text { tion. }\end{array}$ & $\begin{array}{l}\text { Portable equip- } \\
\text { ment available, in- } \\
\text { tensity of radia- } \\
\text { tion can be varied. }\end{array}$ & $\begin{array}{l}\text { Dangerous radia- } \\
\text { tion; portable } \\
\text { units have low in- } \\
\text { tensities and field } \\
\text { applications } \\
\text { limited to wooden } \\
\text { and thin com- } \\
\text { ponents; opposite } \\
\text { surface of compo- } \\
\text { nent must be ac- } \\
\text { cessible. }\end{array}$ \\
\hline $\begin{array}{l}13.2 \text { Gamma } \\
\text { Radiography }\end{array}$ & $\begin{array}{l}\text { Gamma radiation } \\
\text { attenuates when } \\
\text { passing through a } \\
\text { building compo- } \\
\text { nent. Extent of at- } \\
\text { tenuation controll- } \\
\text { ed by density and } \\
\text { thickness of the } \\
\text { materials of the } \\
\text { building compo- } \\
\text { nent. Photo- }\end{array}$ & $\begin{array}{l}\text { Locating internal } \\
\text { cracks, voids and } \\
\text { variations in den- } \\
\text { sity and composi- } \\
\text { tion of materials. } \\
\text { Locating internal } \\
\text { parts in a building } \\
\text { component, e.g. } \\
\text { reinforcing steel in } \\
\text { concrete. }\end{array}$ & $\$ 5000$ to $\$ 10,000$ & $\begin{array}{l}\text { Must be operated } \\
\text { by trained and } \\
\text { licensed person- } \\
\text { nel. }\end{array}$ & $\begin{array}{l}\text { Portable and } \\
\text { relatively inexpen- } \\
\text { sive compared to } \\
\text { X-ray radio- } \\
\text { graphy; internal } \\
\text { defects can be } \\
\text { detected; ap- } \\
\text { plicable to a varie- } \\
\text { ty of materials. }\end{array}$ & $\begin{array}{l}\text { Radiation intensi- } \\
\text { ty cannot be ad- } \\
\text { justed; long ex- } \\
\text { posure times may } \\
\text { be required; } \\
\text { dangerous radia- } \\
\text { tion; two opposite } \\
\text { surfaces of compo- } \\
\text { nent must be ac- } \\
\text { cessible. }\end{array}$ \\
\hline
\end{tabular}


Table 3. (Cont.)

\begin{tabular}{|c|c|c|c|c|c|c|}
\hline Method & Principle & $\begin{array}{c}\text { Main } \\
\text { Applications }\end{array}$ & $\begin{array}{c}\text { Equipment } \\
\text { Cost }\end{array}$ & $\begin{array}{c}\text { User } \\
\text { Expertise }\end{array}$ & Advantages & Limitations \\
\hline
\end{tabular}

graphic film

record usually

made, which is

analyzed.

\begin{tabular}{|c|c|c|c|c|c|c|}
\hline $\begin{array}{l}\text { 14. Seismic } \\
\text { Testing }\end{array}$ & $\begin{array}{l}\text { Integrity of } \\
\text { material evaluated } \\
\text { by analysis of } \\
\text { shock wave } \\
\text { transmission and } \\
\text { effects. Shock } \\
\text { wave induced by }\end{array}$ & $\begin{array}{l}\text { Determination of } \\
\text { soil densities and } \\
\text { variation in den- } \\
\text { sities. Also vibra- } \\
\text { tional characteris- } \\
\text { tics of buildings } \\
\text { can be determin- }\end{array}$ & $\begin{array}{l}\text { Wide, depending } \\
\text { on amount of in- } \\
\text { formation desired. }\end{array}$ & $\begin{array}{l}\text { Experience re- } \\
\text { quired to plan test } \\
\text { and to interpret } \\
\text { results. }\end{array}$ & $\begin{array}{l}\text { Large area of soil } \\
\text { and entire struc- } \\
\text { ture in its "as- } \\
\text { built" condition } \\
\text { can be tested. }\end{array}$ & $\begin{array}{l}\text { If incorrectly } \\
\text { placed, explosive } \\
\text { charge could } \\
\text { damage structure; } \\
\text { care must be exer- } \\
\text { cised in handling } \\
\text { explosives. }\end{array}$ \\
\hline
\end{tabular}

explosive charges ed.

and transmission

detected by

transducers.

\begin{tabular}{|c|c|c|c|c|c|c|}
\hline $\begin{array}{l}15.1 \text { Indentation } \\
\text { Hardness Test }\end{array}$ & $\begin{array}{l}\text { Pointed probe is } \\
\text { mechanically forc- } \\
\text { ed into surface of } \\
\text { a material, usually } \\
\text { a metal, under a } \\
\text { specified load. } \\
\text { The depth of iden- } \\
\text { tification is }\end{array}$ & $\begin{array}{l}\text { Determination of } \\
\text { effectiveness of } \\
\text { heat treatment on } \\
\text { hardness of } \\
\text { metals. Esti- } \\
\text { mating tensile } \\
\text { strength of metals. }\end{array}$ & $\$ 600$ to $\$ 4000$ & Low. & $\begin{array}{l}\text { Portable equip- } \\
\text { ment available; } \\
\text { fast and easy test } \\
\text { to perform. }\end{array}$ & $\begin{array}{l}\text { Conversion tables } \\
\text { give only approx- } \\
\text { imate tensile } \\
\text { strengths; } \\
\text { feasibility of } \\
\text { testing limited by } \\
\text { size and geometry } \\
\text { of component. }\end{array}$ \\
\hline
\end{tabular}

measured and

strength of

materials may be

estimated.

\begin{tabular}{ll}
\hline 15.2 Rebound & Spring driven \\
Hammer & mass strikes sur- \\
& face of concrete \\
and rebound \\
distance is given \\
in R-values. Sur- \\
face hardness is \\
measured.
\end{tabular}

16. Thermal In-
spection

spection

Heat sensing
devices are used to
detect irregular
temperature
distributions due
to presence of
flaws or in-
homogenities in a
material or com-
ponent that have
different im-
pedances to heat
flow. Contours of
equal temperature
(thermography) or
temperatures
(thermometry) are
measured over the
test surface with

\begin{tabular}{|c|c|c|c|c|}
\hline $\begin{array}{l}\text { Estimation of } \\
\text { compressive } \\
\text { strength, unifor- } \\
\text { mity and equality } \\
\text { of concrete. }\end{array}$ & $\$ 250$ to $\$ 600$ & $\begin{array}{l}\text { Low, can be readi- } \\
\text { ly operated by } \\
\text { field personnel. }\end{array}$ & $\begin{array}{l}\text { Inexpensive; large } \\
\text { amount of data } \\
\text { can be quickly ob- } \\
\text { tained; good for } \\
\text { determining } \\
\text { uniformity of con- }\end{array}$ & $\begin{array}{l}\text { Results affected } \\
\text { by condition of } \\
\text { concrete surface; } \\
\text { does not give } \\
\text { precise prediction } \\
\text { of strength. }\end{array}$ \\
\hline
\end{tabular}

Detection of heat loss through walls and roofs; detection of moisture in roofs; detection of delamination in composite materials.

$\$ 30,000$ for in-
frared scanning
camera. Less ex-
pensive hand held
equipment becom-
ing commercially
available.

Moderate to extensive depending on nature of test.

\author{
Portable; perma- Costly equipment; \\ nent record can be referenced stan- \\ made; testing can dards needed; \\ be done without means of produc- \\ direct access to ing thermal gra- \\ surface and large dient in test com- \\ area can be rapid- ponent or material \\ ly inspected using is required.
}


Table 3. (Cont.)

\begin{tabular}{|c|c|c|c|c|c|c|}
\hline Method & Principle & $\begin{array}{c}\text { Main } \\
\text { Applications }\end{array}$ & $\begin{array}{c}\text { Equipment } \\
\text { Cost }\end{array}$ & $\begin{array}{c}\text { User } \\
\text { Expertise }\end{array}$ & Advantages & Limitations \\
\hline & $\begin{array}{l}\text { contact or non- } \\
\text { contact detection } \\
\text { devices. A com- } \\
\text { mon detection } \\
\text { device is an in- } \\
\text { frared scanning } \\
\text { camera. }\end{array}$ & & & & & \\
\hline $\begin{array}{l}\text { 17.1 Ultrasonic } \\
\text { Pulse Velocity }\end{array}$ & $\begin{array}{l}\text { Based on measur- } \\
\text { ing the transit } \\
\text { time of an induced } \\
\text { pulsed compres- } \\
\text { sional wave pro- } \\
\text { pagating through } \\
\text { a material. }\end{array}$ & $\begin{array}{l}\text { Eatimation of the } \\
\text { quality and } \\
\text { uniformity of con- } \\
\text { crete. }\end{array}$ & $\$ 4000$ to $\$ 6000$ & $\begin{array}{l}\text { Low level required } \\
\text { to make measure- } \\
\text { ments. }\end{array}$ & $\begin{array}{l}\text { Excellent for } \\
\text { determining the } \\
\text { quality and } \\
\text { uniformity of con- } \\
\text { crete; test can be } \\
\text { quickly perform- } \\
\text { ed. }\end{array}$ & $\begin{array}{l}\text { Does not provide } \\
\text { estimate of } \\
\text { strength; skill re- } \\
\text { quired in analysis } \\
\text { of results; } \\
\text { moisture variation } \\
\text { can affect results. }\end{array}$ \\
\hline $\begin{array}{l}17.2 \text { Ultrasonic } \\
\text { Pulse Echo }\end{array}$ & $\begin{array}{l}\text { Pulse compres- } \\
\text { sional waves are } \\
\text { induced in } \\
\text { materials and } \\
\text { those reflected } \\
\text { back are detected. } \\
\text { Both the transmit- } \\
\text { ting and receiving } \\
\text { transducers usual- } \\
\text { ly are contained in } \\
\text { the same probe. }\end{array}$ & $\begin{array}{l}\text { Inspecting metals } \\
\text { for internal } \\
\text { discontinuities. } \\
\text { Some work has } \\
\text { been performed } \\
\text { on the use of the } \\
\text { pulse echo method } \\
\text { to inspect con- } \\
\text { crete. }\end{array}$ & Minimum $\$ 5000$ & $\begin{array}{l}\text { High level of ex- } \\
\text { pertise required to } \\
\text { interpret results. }\end{array}$ & $\begin{array}{l}\text { Portable; internal } \\
\text { discontinuities can } \\
\text { be located and } \\
\text { their sizes } \\
\text { estimated. }\end{array}$ & $\begin{array}{l}\text { Good coupling } \\
\text { between } \\
\text { transducer and } \\
\text { test substrate } \\
\text { critical; inter- } \\
\text { pretation of } \\
\text { results can be dif- } \\
\text { ficult; calibration } \\
\text { standards re- } \\
\text { quired. }\end{array}$ \\
\hline $\begin{array}{l}\text { 18.2 Fiberscope } \\
\text { (Endoscope) }\end{array}$ & $\begin{array}{l}\text { Bundle of flexible, } \\
\text { optical fibers with } \\
\text { lens and illumi- } \\
\text { nating systems is } \\
\text { inserted into small } \\
\text { bore hole thus } \\
\text { enabling view of } \\
\text { interior of cavities. }\end{array}$ & $\begin{array}{l}\text { Check condition } \\
\text { of materials in } \\
\text { cavity, such as } \\
\text { thermal insulation } \\
\text { in wall cavities, } \\
\text { pipes and elec- } \\
\text { trical wiring in } \\
\text { cavity walls; check } \\
\text { for unfilled cores } \\
\text { in reinforced } \\
\text { masonry construc- } \\
\text { tion; check for } \\
\text { voids along. } \\
\text { grouted stressed } \\
\text { tendons. }\end{array}$ & $\$ 3000$ to $\$ 6000$ & Low. & $\begin{array}{l}\text { Direct visual in- } \\
\text { spection of other- } \\
\text { wise unaccessible } \\
\text { parts is possible. }\end{array}$ & $\begin{array}{l}\text { Probe holes usual- } \\
\text { ly must be drilled; } \\
\text { probe holes must } \\
\text { connect to a . } \\
\text { cavity. }\end{array}$ \\
\hline $\begin{array}{l}\text { 18.3 Eiquid } \\
\text { Penetrant Inspec- } \\
\text { tion }\end{array}$ & $\begin{array}{l}\text { Surface is covered } \\
\text { with a liquid dye } \\
\text { which is drawn in- } \\
\text { to surface cracks } \\
\text { and voids. } \\
\text { Developer is ap- } \\
\text { plied to reveal } \\
\text { presence and loea- } \\
\text { tion of flaws. }\end{array}$ & $\begin{array}{l}\text { Detection of sur- } \\
\text { face cracks and } \\
\text { flaws. Usually } \\
\text { used to inspect } \\
\text { metals. }\end{array}$ & $\begin{array}{l}\$ 50 \text { to } \$ 250 \text { per } \\
100 \text { linear feet of } \\
\text { inspection. }\end{array}$ & Low. & $\begin{array}{l}\text { Inexpensive; easy } \\
\text { to use; can be ap- } \\
\text { plied to complex } \\
\text { parts; results are } \\
\text { easy to interpret. }\end{array}$ & $\begin{array}{l}\text { Detects only sur- } \\
\text { face flaws, false } \\
\text { indications possi- } \\
\text { ble on rough or } \\
\text { porous materials; } \\
\text { surface requires } \\
\text { cleaning prior to } \\
\text { testing. }\end{array}$ \\
\hline
\end{tabular}




\section{REFERENCES}

[ 1] Metals Handbook, Vol. 11, Nondestructive Inspection and Quality Control, 8th Edition (American Society of Metals, Metals Park, Ohio, 1976).

[ 2] Botsco, R.J., Specialized NDT Methods, Lesson 12, Fundamentals of Nondestructive Testing (Metals Engineering Institute, 1977).

I 3] Tentative Test Method for Pullout Strength of Hardened Concrete, American Society for Testing and Materials (ASTM) Designation C900-78T.

[ 4] Malhotra, V.M., Testing Hardened Concrete: Nondestructive Methods, American Concrete Institute Monograph No. 9 (Detroit, 1976).

[ 5] Richards, O., Pullout Strength of Concrete, in Reproducibility and Accuracy of Mechanical Testing, ASTM STP626, pp. 3240, (1977).

[ 6] Mailhot, G., Bisaillon, A., Carrette, G.G., and Malhotra, V.M., In-Place Concrete Strength: New Pullout Methods, ACI Journal. Vol. 76, pp. 1267-1282 (1979).

[ 7] Clear, K.C., and Hay, R.E., Time-to-Corrosion of Reinforcing Steel in Concrete Slabs, Vol. 1, Effects of Mix Design and Construction Parameters, Federal Highway Administration Report. No. FHWA-RD073-32 (W ashington, D.C., 1973).

[ 8] McGonnagle, W.J., Nondestructive Testing, Gordan and Breach, New York, (1969).

[ 9] Sevall, G.W., Nondestructive Testing of Construction Materials and Operations, Construction Engineering Research Laboratory Technical Report M-67 (Champaign, Illinois, 1973).

[10] Dunn, F.W., Magnetic Particle Inspection Fundamentals, Lession 3, ref. 2.

[11] Betz, C.E., Magnetic Particle Inspection Applications, Lesson 4, ref. 2.

[12] Cantor, T.R. and Knecter, C.P., Verification of Radar NDE of $700 \mathrm{ft}$ of the GWB, PAIVYNI Engineering R \& D Report No. El-3 (New York Port Authority, 1981).

[13] Cantor, T.R. and Knecter, C.P., Radar and Acoustic Emission Applied to Study of Bridge Decks Suspension Cables and Masonry Tunnel, Transportation Research Paper 676 (1978).

[14] Alongi, A.V., Radar Examination of Condition of Two Interstate Highway Bridge decks, Penetradar Corp. (Niagara Falls, 1973).

[15] Bushing, H., Mathey, R., Rossiter, W., and Cullen, W., Effects of Moisture in Built-up Roofing-A State-of-the-Art Literature Survey, National Bureau of Standards Technical Note 965 (1978).

[16] Boot, A. and Watson, A., Applications of Centimetric Radiowaves in Nondestructive Testing, in Application of Advanced and Nuclear Physics to Testing Materials, ASTM STP-373, pp. 3-24 (1965).

17] Jenkins, D.R., Knab, L.J., and Mathey, R.G., Moisture Detection in Roofing by Nondestructive Means, A Stateof-the-Art Survey, National Bureau of Standards Technical Note 146 (1981).

18] Knab, L., Mathey, R., and Jenkins, D., Laboratory Evaluation of Nondestructive Methods to Measure Moisture in Built-Up Roofing Systems, National Bureau of Standards Building Science Series 131 (1981).

19] Tobiasson, W. and Korhonen, C., Summary of Corps of Engineering Research on Roof Moisture Detection and the Thermal Resistance of Wet Insulation, Cold Regions Research and Engineering Laboratory Special Report 78-29 (1978).
Test for Penetration Resistance of Hardened Concrete, ASTM Designation C803.

[21] Arni, H.T., Impact and Penetration Resistance Tests of Portland Cement Concrete, Federal Highway Administration Report No. FHWA-RD-73-5 (1972).

[22] Aman, J.K., Carney, G.M., McBride, D., and Turner, R.E., Radiographic Fundamentals, Lesson 8, ref. 2.

[23] McBride, D., Carney, G., Turner, R., and Lomerson, E.O., Fundamentals of Radiography, Lesson 9, ref. 2.

[24] Forrester, J.A., Gamma Radiography of Concrete, Proceedings of Symposium on Nondestructive Testing of Concrete and Timber, Session No. 2, pp. 9-13, Institute of Civil Engineers (London, 1969).

[25] Standard Hardness Conversion Tables for Metals, ASTM Designation E140.

[26] Shore, A.T., Properties of Hardness in Metals and Materials, Proceedings ASTM, Vol. 9, pg. 733, (1911).

[27] Schmidt, E., A Nondestructive Concrete Test, Concrete, Vol. 59, (No. 8), pg. 34 (1951).

[28] Clifton, J.R., Nondestructive Test to Determine Concrete Strength-A Status Report, NBSIR 75-729, National Bureau of Standards (1975).

[29] Peterson, P.H. and Stoll, V.W., Relation of Rebound Hammer Test Results to Sonic Modulus and Compressive-Strength Data, Proceedings, of Highway Research Board, Vol. 34, pg. 387, (1955).

[30] Boundy, C. and Hondrus, G., Rapid Field Assessment of Strength of Concrete by Accelerated Curing and Schmidt Rebound Hammer, Journal of American Concrete Institute, Vol. 61, (No. 1), pg. 1 (1964).

[31] Victor, D.J., Evaluation of Hardened Field Concrete with Rebound Hammer, Indian Concrete Journal, Vol. 37, (No. 11), pg. 407 (1963).

[32] Green, G.W., Test Hammer Provides New Method of Evaluating Hardened Concrete, Journal of American Concrete Institute, Vol. 26, (No. 3), pg. 249, (1954).

[33] Discussion of Reference 32, Journal of American Concrete Institute, Vol., 27 (No. 4), pg. 256, (1955).

[34] Mitchel. L.J., and Hoagland, G.G., Investigation of the Impact-Type Concrete Test Hammer, Highway Research Board Bulletin 305, pg. 14, (1961).

[35] Williams, C.H., Investigation of the Schmidt Concrete Test Hammer, Miscellaneous Report No. 6-267, U.S. Army Engineer Waterways Experiment Station (Vicksburg, Mississippi, 1958).

[36] Discussion of Reference 29 by Klieger, Proceedings of Highway Research Board, Vol. 34, pg. 392, (1955).

[37] Erickson, G.A., Investigation of the Impact-type Concrete Test Hammer, Model II, Concrete Laboratory Report C928, Division of Engineering Laboratories, Dept. of the Interior (Denver, 1959).

[38] Manning, D.G. and Holt, F.B., Detecting Delamination of Concrete Bridge Decks, Concrete International, Vol. 2, No. 11, pg. 34-41 (1980).

[39] Smith, A.L., Ultrasonic Testing Fundamentals, Lesson 5, ref. 2.

[40] Lovelace, J.F., Ultrasonic Testing Equipment, Lesson 6, ref. 2.

[41] Moberg, A.J., Ultrasonic Testing Applications, Lesson 7, ref. 2.

[42] Whitehurst, E.A., Evaluation of Concrete Properties from Sonic Tests, American Concrete Institute Monograph No. 2 (Detroit, 1966).

[43] Leslie, J.R. and Cheesman, W.J., An Ultrasonic Method 
of Studying Deterioration and Cracking in Concrete Structures, Journal of American Concrete Institute, Vol. 46, (No. 1); pp. 17-36 (1949).

[44] Parker, W.E., Pulse Velocity Testing of Concrete, Proceedings ASTM, Vol. 53, pg. 1033 (1953).

[45] Jones, R., Nondestructive Testing of Concrete, Cambridge University Press, Oxford, (1962).

[46] Lomerson, E.O., Liquid Penetrants, Lesson 2, ref. 2.

[47] Jones, R. and Facaoaru, Analysis of Answers to a Questionnaire on the Ultrasonic Pulse Technique, RILEM Materials and Structures, Vol. 1 (No. 5), pg. 457 (1968).

[48] Wiebenga, J.G., A Comparison Between Various Combined Nondestructive Testing Methods to Derive the Comprehensive Strength of Concrete, Report No. B168-61/IHI.8, Institut TNO Voor Bouwmaterialen en Bouwconstructies, (Delft, Netherlands, 1968).

[49] Galan, A., Estimate of Concrete Strength by Ultrasonic
Pulse Velocity and Damping Constant, Journal of American Concrete Institute, Vol. 64, No. 10, pg. 678 (1967).

Facaoaru, I., Nondestructive Testing of Concrete in Romania, Paper 4C, Symposium on Nondestructive Testing of Concrete and Timber, Institution of Civil Engineers, (London, 1969).

[51] Facaoaru, I., Dumitrescu, I., and Constaninescu, L., Concrete Strength Determination by Nondestructive Combined Methods, RILEM Report, Aachen, 41 (1966).

[52] Facaoaru, I., Dumitrescu, I., and Stamate, G., New Developments and Experience in Applying Combined Nondestructive Methods for Testing Concrete, RILEM Report, Varna, 26 (1968).

[53] Facaoaru, I., Chairman's Report of the RILEM Committee on Nondestructive Testing of Concrete, RILEM, Materials and Structures, Vol. 2, No. 10, pg. 253 (1969). 